
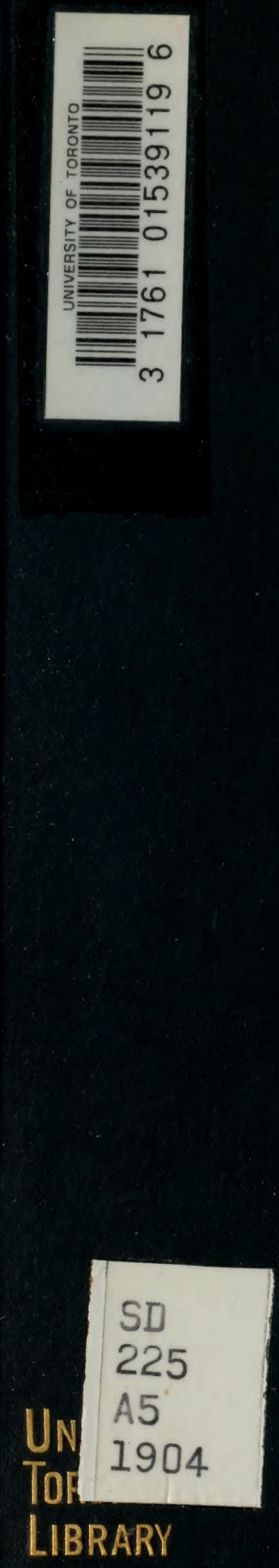

Digitized by the Internet Archive in 2010 with funding from University of Toronto

http://www.archive.org/details/forestryofjapa00japa 



\title{
FORESTRY OF JAPAN
}
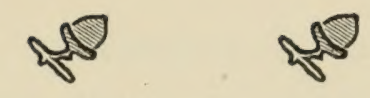

is

PUBLISHED BY

\section{IMPERIAL BUREAU OF FORESTRY}

\begin{abstract}
DEPARTMENT OF AGRICULTURE AND COMMERCE
T O KY $\mathrm{O}$
\end{abstract}

is

Printed at the "Japan times" Office

\section{4}

LIBRARY

FACULTY OF FORESTRY

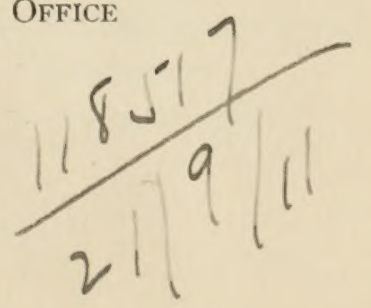

UNIVERSITY OF TORONTO 

This work aims to give an adequate idea of forestry in Japan, and treats of State, Crown, and private forests. More attention is naturally given to State and Crown forests on account of the insufficiency of information about private forests.

All the data were prepared by the Department of Agriculture and Commerce being mostly taken from report for 1902, when the data for that year were not available, the reports for 1903 or 1901 were used, preference being given to the later year.

As the units of distance, ri, cho, ken, and shaku have been used, equivalent to about $2 \frac{1}{2}$ miles, 1,200 yards, $6 \mathrm{ft}$. and $1 \mathrm{ft}$. respectively.

The unit of capacity is the koku, equivallent to 181 litres.

The unit of weight is the kin, which is almost equal to $1 \frac{1}{3}$ lbs.

The unit of area is the cho, equal to about $2 \frac{1}{2}$ acres.

The unit for measuring timber is the shakujime, equivalent to $12 \mathrm{cu}$. ft., and that for fuel wood is the tana, or $72 \mathrm{cubic} \mathrm{ft}$.

The monetary unit is the yen, equal to about $\$ 0.50$ U.S. gold.

In many cases, the dates are given according to the Japanese system the first year of Meiji being 1868 .

All the reports are made for the fiscal year which extending from April 1st to March 31st.

The common Japanese names of trees together with the botanical ones are given.

Tokyo, March 1904.

F. GOTO.

Commissioner for Bureau of Forestry, Detartment of Agriculture and Commerce. 



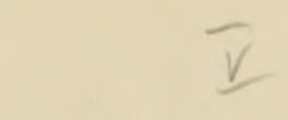

\section{CONTENTS.}

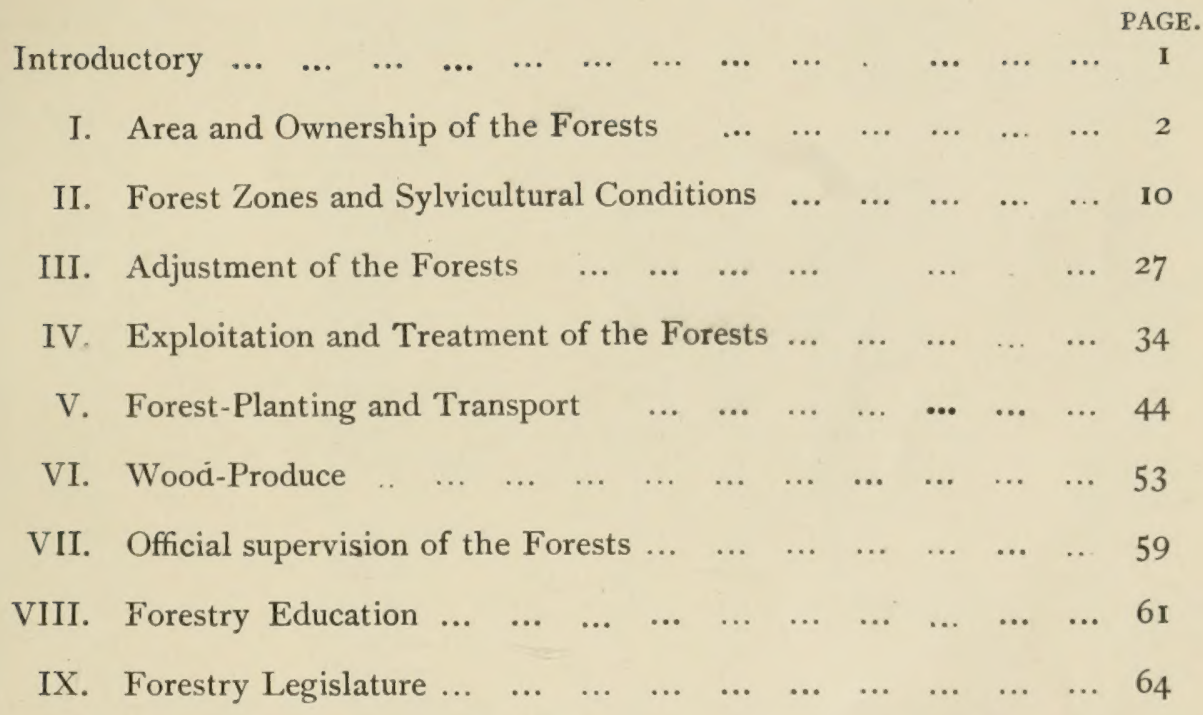





\section{ERRATA.}

\begin{tabular}{|c|c|c|c|c|c|c|c|}
\hline Page & Line & For & Read & Page & Line & For & Read \\
\hline 2 & 30 & 1890 & 1901 & 32 & 36 & \multicolumn{2}{|l|}{ add area after whose } \\
\hline 4 & $2 \mathrm{I}$ & 1904 & 1914 & 35 & 4 & 'Tókaidō & Takaido \\
\hline 4 & 32 & I 889 & 1894 & 35 & 5 & Kii & Yoshino \\
\hline 5 & 4 & 1889 & I 872 & 35 & II & of high forest & the treatment of \\
\hline 5 & 5 & $\mathbf{1}, 453,342$ & $\mathbf{I}, 443,342$ & & & treatment & high rotation \\
\hline 9 & I & $2,314,296$ & $3,283,306$ & 37 & 35 & "Motoki" " & "Honboku" \\
\hline 9 & 2 & $3 \pi / 2$ & 4.7 & 37 & 35 & "Nami-motoki" " & "Nami-hon- \\
\hline IO & I4 & four & seven & & & & boku" \\
\hline 10 & 15 & July & October & 38 & 3 & 14 & 13 \\
\hline I I & 20 & aers & areas & 38 & 6 & "Motoki" & "Honboku" \\
\hline 12 & 6 & Arctic & Frigid & 38 & 8 & "Motoki" & "Honboleze" \\
\hline 13 & 12 & Camphore & Camphora & 42 & I6 & Tufa & T'uff \\
\hline 13 & 32 & Boxus & Buxus & 42 & 17 & Kōluke & Kōtsuke \\
\hline 14 & 4 & Kawara & Kaharu & 42 & 35 & Bicho & Binclio \\
\hline 15 & 5 & Shite & Shicle & 43 & 30 & Shivobe & Shirabe \\
\hline 15 & 8 & oak & Ubamekashi & 43 & 30 & $\begin{array}{l}\text { Tosa } \\
\cos 8\end{array}$ & $1 \operatorname{sic} \theta$ \\
\hline 15 & 28 & Shite & Shicle & 45 & 6 & I 888 & 1878 \\
\hline 16 & 22 & $\begin{array}{l}\text { thenbergi } \\
\text { Sieb }\end{array}$ & Thunbergii & 47 & 5 & 485,727 & $48,572,7$ \\
\hline 16 & 35 & $\begin{array}{l}\text { Sieb } \\
\text { Yakujima }\end{array}$ & Yakushima & $\begin{array}{l}47 \\
47\end{array}$ & 25 & 658,402 & $\begin{array}{l}65,840,2 \\
7.6\end{array}$ \\
\hline $\begin{array}{l}19 \\
19\end{array}$ & $\begin{array}{r}7 \\
27\end{array}$ & $\begin{array}{l}\text { Yakujıma } \\
\text { Abias }\end{array}$ & $\begin{array}{l}\text { Yakushıma } \\
\text { Abies }\end{array}$ & 47 & $\begin{array}{l}25 \\
25\end{array}$ & $\begin{array}{l}3.3 \\
1.7\end{array}$ & $\begin{array}{l}7.0 \\
9.7\end{array}$ \\
\hline 20 & 12 & Toshima & Oshima & 48 & II & with conifers & of conifers with \\
\hline 20 & 15 & Arctic & Frigid & & & & broad-leafed \\
\hline 20 & I9 & bicolos & bicolor & & & & trees \\
\hline 22 & 17 & drazo out only a & ld important & 48 & I $2-13$ & 3 plan-ing & planting \\
\hline 22 & I6 & add in Hokkaido & after timbers & 48 & 13 & broad-leafed trees & mixed woods \\
\hline 23 & 18 & Mesm. & Wesm. & 48 & $3^{2}$ & brood-leafed & other \\
\hline 23 & 28 & 6 & 20 & $5^{I}$ & $14-16$ & Devdara & deorata \\
\hline 23 & 37 & specie & species & 55 & 4 & 1892 & I895 \\
\hline 24 & 12 & not & the & 55 & 35 & 669,149 & 699,149 \\
\hline 24 & 13 & drace out any & & 56 & 7 & 0.082 & 0.092 \\
\hline 24 & 21 & Leavis & Laivis & 56 & 10 & 340 & 240 \\
\hline 24 & 22 & $\begin{array}{l}\text { add var. puvin } \\
\text { D.C. }\end{array}$ & ervis wg. after & $\begin{array}{l}56 \\
57\end{array}$ & $\begin{array}{l}12 \\
15\end{array}$ & 22 & $3^{2}-8640$ \\
\hline 25 & 5 & Sachaliensis & sachalinensis & $5^{8}$ & 4 & $\begin{array}{l}1,950,140 \\
0.095\end{array}$ & $\begin{array}{l}1,950,040 \\
0.099\end{array}$ \\
\hline 25 & Io & Tarunai & 'Tarumai & 58 & 4 & 0.533 & 0.532 \\
\hline 25 & I I & ()toneton & ()nneton & $5^{8}$ & 27 & 0.337 & 0.237 \\
\hline 25 & 33 & Gaeten & Gaerten & 59 & I & 0045 & 0.073 \\
\hline 29 & 35 & 1903 & 1913 & 59 & 1 & 0.125 & 0.232 \\
\hline 32 & 30 & contour & polyganol & 59 & 2 & 0.138 & 0.225 \\
\hline $3^{2}$ & 35 & $\begin{array}{l}\text { Add until } 1901 \\
\text { ment }\end{array}$ & after measure- & 59 & 3 & 0.093. & 0.218 \\
\hline 32 & 36 & contour & polygonal & & & Offices & \\
\hline
\end{tabular}





\section{F ORESTR Y}

or

\section{J A P AN.}

\section{INTRODUCTORY.}

Tre forests of Japan, her natural ornament, which occupy more than one half the area of the Island Empire, would appear to have exerted an inspiring influence upon the mind of her inhabitants, for their love of forests and the luxuriant sylvan growth is observed to he almost intuitive. We are also inclined to think that the Japanese may owe their patriotism and aesthetic sense to the profoundly sympathetic influence the forests seem to have exercised upon them. They are instinctively aware of their duties, - so to sperk-towards the forests as is indicated by the endearors they never spare to meet the ever increasing demand for the produce of the forest, to change them in accordance with the ne requirements and to maintain their supplies permanently.

The forests of Japan, had, while the country was secluded, maintained their primitive character, but with the Restoration the forests underwenit a revolution in the extent and modes of their utilization. Besides a considerable increase at home in the demand for timber and fuel not only in connection with industrial and min- 
ing enterprises and for ordinary building purposes, but also for use as railroad sleepers and telegraph poles as well as for the manufacture of the various wood articles and paper, the recent development in the carrying trade has caused the traders in forest produce to seek customers abroad, especially in China and Korea. All this has in recent years exercised an unequal influence on Japanese forests so that, while, on the one hand, there are districts where reckless felling and all the evils resulting from it have obliged the Government to exercise control as to cutting, on the other hand there are in some parts of the country vast areas of wooded-land maintaining all its primitive features unaltered.

This anomaly has brought to light the fact that the plans hitherto followed in the management of forests are no longer adequate to meet the future increase of the population and the requirements of the new civilization, but points to the necessity for striving to develop to the full the natural capabilities of the forests by increasing their productive powers by the application of regular technical methods.

\section{AREA AND OWNERSHIP OF THE FORESTS.}

The Area.-According to the latest statistics the area occupied by forests is $23,087,365$ cho, i.e. over 59 per cent. of the whole area of the country which measures $24,794.36$ square $r i$ or $38,559,078$ cho. (The area of Formosa and the Pescadores is not included in the above computation, not having yet been ascertained.)

Of the two divisions in the Japanese forests, "Utilization Forests" and "Protection Forests," the latter are further divided into two kinds, "Absolute" and "Ordinary." The area of the Protection Protection forests in 1909 was 689,469 cho of which Forests. 4,803 cho belonged to the "Alsolute" class and 684,662 cho to the "Ordinary" category. All the other forests belong to the Utilization class, measuring $22,397,896$ 
cho. Those forests exclusively maintained for the utilization of their produce are left to be managed by the owners Utilization as they like. Those forests of this class which belong Forests. to the State and Imperial Household are generally managed and tended in accordance with modern technical rules and bid fair to become greatly improved with regard to their productiveness. But those owned by the people, with the exception of a very small number, are entirely left to nature, nothing being done to increase their utility.

Ownership of the Forests. - The areas of the forests of these different, ownerships are as follows:-

cho.

$\begin{array}{lllllllllll}\text { States Forests } & \ldots & \ldots & \ldots & \ldots & \ldots & \ldots & \ldots & \ldots & \ldots & \mathbf{1 3}, \mathbf{1 2 5 , 3 2 0} \\ \text { Imperial Forests } & \ldots & \ldots & \ldots & \ldots & \ldots & \ldots & \ldots & \ldots & 2,091,785 \\ \text { People's Forests } & \ldots & \ldots & \ldots & \ldots & \ldots & \ldots & \ldots & \ldots & 7,870,260\end{array}$

The people's forests comprise those owned by Shinto and Buddhist temples, communes and private individuals, their respective areas being as follows:-

\begin{tabular}{|c|c|c|c|c|c|c|}
\hline Shinto and Buddhist & Temple Forests & $\ldots$ & $\ldots$ & ... & ... & 167,629 \\
\hline Communal Forests & $\begin{array}{lll}\ldots & \ldots & \ldots\end{array}$ & ... & $\ldots$ & $\ldots$ & ... & $1,714,754$ \\
\hline Private Forests ... & $\ldots$ & ... & ... & ... & ... & $5,987,877$ \\
\hline
\end{tabular}

State Fonests. - The State forests are managed by the Government and by the Imperial Household Department, while over the people's forests the Government merely exercise administrative supervision in accordance with the provisions of the Forest Law.

Of the State forests measuring $13,125,320$ cho, 7,632,831 cho are under the jurisdiction and management of the Agricultural and Commercial Department of the Imperial Government, but $5,492,489$ cho in Hokkarido a are placed under the control of the Home Department. The forests in Formosa are maintained according to speciai laws and regulations by the Governor-General under the supervision of the Minister for Home Affairs. 
These figures are not, it must be owned, the result of accurate scientific surveying, the statistics relating to the State and Inperial forests being taken from the Government Forest Register compiled according to the Provisional Regulations for Government Forests of 1875 and those relative to the people's forests from the Land Register prepared by the Treasury Department for the purpose of taxation in accordance with the Regulations for the Revision of the Land Tax established in 1873. These registers being based on very rough surveys the firures above mentioned will have to be more or less modified, when the work of forest adjustments and investigation now going on shall have been completed. Inaccuracies are especially likely to be found in the case of the people's forests for, as the years went by, there must have been lands converted from other classes of land into forests and from forests into farm or building lots.

In this period of renovations the areas of forests are subject to changes both absolutely and in respect of proprietorship, as transfers and conversion into other classes of estates are taking place and such changes will not cease until the completion in 194 of the work of the special State forest adjustment undertaken by the Government.

Imperial Forests.-In 1899 States forests in Kanagawa, Yamanashi, Shizuoka, Nagano, Gifu, Aichi, Miye, Aomori, Iwate and Tochigi prefectures and Hoklaido, to the extent of 3,649'848 cho in all, were transferred to the Imperial Household to constitute the Imperial forests. These forests being similar to State forests in their nature and features, it goes without saying that some of them are paying concerns, while others are not. In 1892 the Household Department commenced the work of investigating the Imperial forests, as the result of which some of them have been disposed if from time to time since 1898. In 18q4 over 1,370,000 cho in Hokkaido were returned to the State control, while some forests were resold to such temples, Shinto or Buddhist, as had formerly been their possession, in compliance with the regulations established for the special disposal of such forests. Besides, some of those that had been classed as Government property, through criror, on 
the occasion of the land tax revision in the early year of Meiji were restored to their rightful owners. Such transfer not having yet been (ampleted, it will be years before the area of the Imperial forests becomes fixed. From $18 \$ 2$ to 1900 this kind of his Majesty's property increased by 59,533 cho while decreasing by $1,4,53$, 342 cho, so that the clear loss was $1,383,809$ cho. The increace was principally due to the correction of the former computation of areas and to the declaration of lands presenting a sylvan appearance as forests, while the chief causes of the decrease were the expropriation of some forests in Hokkaido and the reclamation and sale of some forests for conversion into arable land.

The Imperial forests are divided into two classes: "Hereditary" and "Ordinary." The former comprises such forests as are so thickly wooled and extensive as to furnish enough material for a regular working plan framed on the basis of economical considerations. Such forests are made extremely difficult of conversion by the Imperial House Law. Hence changes of areas rarely occur except in the forests belonging to the other class. In 1901 there were 997,250 cho of the Hereditary class and 1,100,536 cho of the Ordinary class.

Pervate Forests.-The forests owned by civic corporations, religious establishments and private persons are now subject to greater and more frequent changes than the State and Imperial forests because of the recent slackening of Government control over them and the vicissitudes in the economic conditions of the country. And the decrease of the forest area since the Restoration is mainly due to the reckless felling of woods owned by private persons. We have no statistics showing the extent of such reduction, but see them indirectly shown in the increase of land under cultivation and pasturage. Private forests, however, have increased to a certain extent by the purchase of some State or Imperial property.

Prains AND Moons.-Besides the forests above mentioned there are in this country vast areas of land the uses of which are yet undecided. They are known by the name of "Genya" (plains and moors) as distinguished from forests, being a class of land established on the occasion of the land tax revision. In the early years of Meiji the classification of lands was made merely with 
regard to their features, without paying any attention to their position or nature or to the relations they bear toward each other. Thus the division of land into Forests and "Genya" seems to have been based on no other consideration than the presence or absence of trees. At present there are over 2,645,322 cho of "Genya" which, we may observe, will in the near future, except such portions of them as may from their nature be made into pastures or cultivated land, be mostly converted into forests. This class of land is especially abundant in the northern provinces of the main island and in Hokkaido. Some of the "Genya" already present quite a woody appearance and bid fair to become perfect forests in no distant futures.

Of the above-mentioned area of the "Genya" 1,434,666 cho belong : to the State; 157,174 cho to His Majesty the Emperor, the remaining $1,053,482$ cho being either private or communal pro. perty.

Distribution of Forests.-Forests are found everywhere in the Enpire from Formosa on the south to Hokkaido on the north. But their distribution is varied according to the general shape of the country, the height of the mountains and hills and the density of the population. With the exception of a small number of forests on level ground found here and there, Japanese forests form a long string on the mountains running lengthwise through the middle of the country. In Hokkaido the mountain ranges which traverse the whole island, lengthwise and crosswise, constitute a splendid forest-area. In the main island $a$ Gencral feature chain of forests begins with Momnt Hakodda of Distribution. in Mutsu. It runs through Rikuchū, then appears as Mount Azuma in Uzen, reaches the boundary line between Shinano and Echigo, whence it goes on to form the Kiso forests, where bending southward it runs in an unbroken line from Mount Asama in Shinano to the Imperial forests of Fuji and Amagri lying between the provinces of Kai and Suruga. In the province of $\mathrm{Kii}$ the range starts from Mount Kumano whence it runs to meet the woods in the Yoshino districts, Yamato. In Ghikoku the line crosses the boundary between Sanuki and Awa and proceers over the summit of Mount Ishizuchi to the forests 
in Tosa. In Kyüshu the line is continued through Mount Aso and stretches to Mount Kirishima toward the south. Thus the forests of Japan mostly lie in the mountainous

Distribution as districts along the backbone of the country and to Climate. are scarce on the plains along the seaside. Again they are most numerous in the cold regions in the north and considerably less in the warmer regions in the south, as shown in the following table:-

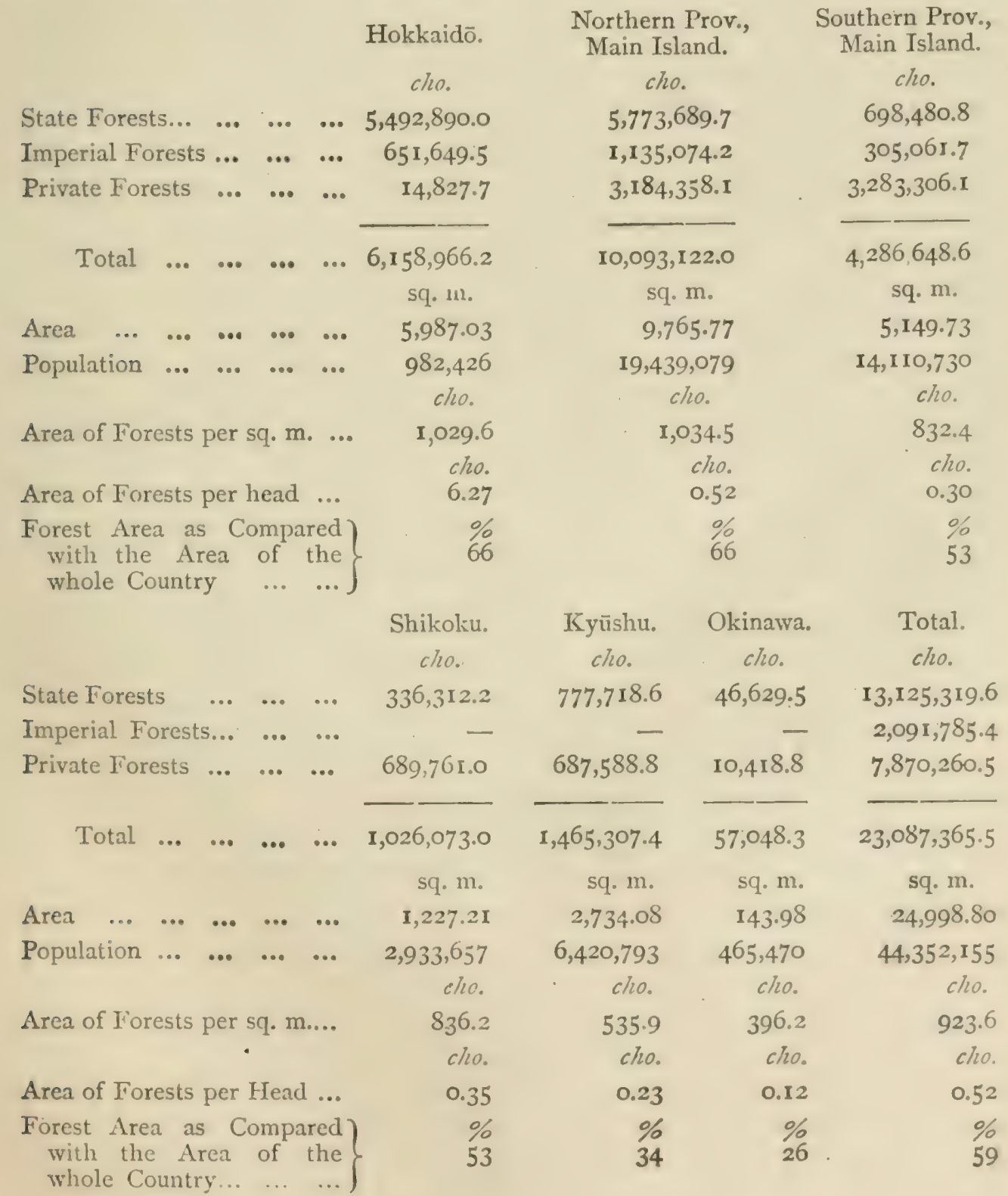




\section{$-8-$}

Note:-1. The above table does not include the forests in Formosa and the Kuriles, which are under investigation at present.

2. The "Northern Provinces, Main Island" in the above table comprise the districts under the jurisdiction of the Aomori, Akita, Miyagi, Tokyo, Nagano, and Major Forestry Offices, while the "Southern Provinces" comprise the districts under the Ósaka, and Hiroshima Offices.

The above table shows that in Hokkaido and in the northern provinces of the main island, forests occupy $66 \%$ of the whole area, while in the Okinawa archipelago only $26 \%$ is wooded land. Kyūshu has $34 \%$ and the southern provinces of the main island and Shikoku have 53\% each. Leaving Hokkaido, which was opened up to colonization only 30 years ago out of consideration for the present, Japan has high and steep mountains in the north which are densely covered with forests. In the middle of the island, near Mount Fuji, the land reaches the utmost elevation and thence toward the south-west the country becomes more and more open, with a range of hills which possesses only a few high mountains. These geographical features have had much to do with the unequal distribution of forests in the country. The difference of economical development in the various districts was also a powerful agent in this connection. In Shikoku, Kyūshu and the western portion of Honshu or the unain island, where civilization made its first appearance in Japan, the people have had better means of transportation than in the other parts of the Empire, and the demand for the timber increasing in proportion to the growth of the population, forests have been rather recklessly felled. This together with the greater need than in other regions for agricultural land must have led to the present scarcity of forest land in these parts. From the standmint of population, Okinawa with 1 tan 2 se of forest land per soul rank the lowest; Kyūshu has 2 tan 3 se; the southern provinces of IIsnshu, 3 tan; Shikoku, 3 tan 5 se; the northern provinces of Honshu, 5 tan 2 se; Hokkaidio where the population is smaller than in any other division of the Empire, enjoys by far the greatest share of firests per soul, to wit; 6 cho 2 tan 7 s\%. In districts having a dense frepulation there are more private and communal forests, especially the fomer, as compared with State forests, than in districts thinly populated. In the southern provinces of Honshū we have 698,480 
cho of State forests agrainst $2,214,296$ cho of private and communal forests, the ratio being $Y_{d} 7$ to 1 in favor of the latter. In Shikoku this ratio is 2 to 1 , while in Kyüshu the two classes of fores are of nearly equal extent. On the contrary, in the northern provinces of Honshu private forests occupy only one-half the area of the State forests. In localities abounding in private or communal forests, the State forests are all situated in remote mountain districts, the forests near market towns having facilities for the transportation of timber being owner either by private individuals or by juridical persons. All these forests except a very few have hitherto been managed without any regard to sound principles and are therefore in a very impoverished condition. Some of them have lately been classed as protection forests in accordance with the provisions of the Forest Law. It is indeed in these districts that the greatest number of protection forests is found.

Ill-managed forests are only too numerous everywhere in the Empire, but their producing capacity being made very small in

Districts of consequence of injudicious cutting, in some disInsuffici:nt Supply. tricts the local forests are inadequate to meet even the ordinary demand for timber. Such is already the case in the southern provinces of Honshu and Kyüshu, where the recent development of mining and industry has produced a considerably increased demand for timber. In those parts the local forests supply little besides wood for the purpose of fuel, and timber is purchased from other districts in yearly increasing quantities. The northern provinces of Honshu and Hokkaicio are yet rich in forests both in regard to area and producingr capaeity, a great number of forests being still placed outsicle the utilization domain. There we find forests in the neighborhood of towns and villages, the produce of which being more than sufficient to meet the local needs for brilding, industrial and mining purpose, is exported to other districts and countries in large quantities. Thus Hokkaidō exports timber to Honshu and to China and Korea for nse in house. and railroad building, Hiba (Thujopsis dolabrata) and Sugi (Cryptomeria japonica) timber produced in Aomori and Akita prefectures is exported not only to Tokyo and Ōsaka but to Shikoku and Kyūshu. 


\section{FOREST ZONES AND SYLVICULTURAL CONDITIONS.}

The geographical position and features of the land, the climate and the geological nature of the soil exercise manifold influences on the species of trees growing in such land and on their rate of growth.

Forest ZoNEs,-Owing to her geographical formation and more particularly to her climatic condition, no place of Japan except a portion of the Kuriles group and a few high mountains, is unfit for the growth of forest trees. We have all species of such trees growing in Japan from those belonging to the Torrid zone to those of the Frigid. Thus Japan is as rich as any country in the world in her arboreal flora. Extremes of temperature are unknown owing to the peculiar distribution of land and water and to the geographical position, the annual average in Formosa being $23^{\circ} \mathrm{C}$. and that of Kamikawa in Hokkaido $5^{\circ} .1$. Taking the averages of the foutur months from April to follys (months, having, so to speak, the greatest influences on the growth of forest trees) we find that Kyüshu indicates $21^{\circ} .2$; Shikoku $20^{\circ} .9$; the southern provinces of Honshu $20^{\circ} .4$ : the northern provinces $18^{\circ} .4$; and in Hakkaido $12 .^{\circ} 7$. The annual average is seldom found even in the high mountain districts to fall below $10^{\circ} \mathrm{C}$. In comparing these with Dove's recornised standard temperatures, it is found that they are higher by $1^{\circ}$ for the summer months and $7^{\circ}$ lower for the winter months.

Sylvicultural Geology. The land occupied by the sylvan flora of Japan has rocks belonging to almost all geological groups from the Achaean to the Cainozoic. They are different in different places and very complex in structure.

The forests in Hokkaido mostly stand on new volcanic rocks and sedimentary rocks, such as sindstone, tuffs, and conglomerate belonging to the Tertiary systom and in a limited space upon Palacenzuic rocks. The forests in the Akita and Aomori prefectures in North Japan are found upon igneous rocks of the Tertiary ystem. In Central Japan the mountain ranges facing the Pacific Ocean geologrically belong to the Archaean and Palaeozoic groups, while the forests in the Kiso districts are flourishing upon granite and other igueous rocks and also upon rocks of the Palaeozoic group. 
The forest land in the Muro districts in the province of Kii is geologically porphyry ejected in the Mesozoic era and the Yoshino forests in Yamato bclong to the Achaean and Palaeozoic groups. The forests in weste:n portion of Honshū, especially Chugoku, stand apon granite, while those in the provinces of Tamba and Tajima are found upon rocks of the Palacozoic group. The mountains of Shikoku like Yoshino in Yamato are composed of Palaeozoic and Archaean rocks. In Kyüshu only the southern section belongs to the Palaeozoic group, the greater part being mostly composed of igneous rocks. This country while fundamentally composed of $A^{\sqrt[r]{c}}$ haean rocks has other strata upon them, which are ejectamenta from volcanoes in the different periods of geological changes. These occasional additions of irneous rocks have been so large that at present nearly one-third of the forest land in the whole country is composed of such rocks, of which the principal rock belonging to the Archaean period is granite and those that were ejected in the Palaenzoic and Mesoznic periods are granite, porphyry, diorite, porphyrite and other's. Of the ejected rocks belonging to the Tertiary and Quaternary periods there is a large number, but those covering larger aers are andesite and basalt.

These rock formations together with other requisites for the growth of forest trees are found to have exercised special influences in accordance with their density and structure upon the generation of the sylvan flora and to possess no snall bearing on the formation of forests.

It is a notable fact that among the extensive forests of coniferous trees that have continued to maintain a fine appearance from ancient times, those depending on natural regeneration are mostly found upon igneous rocks, while the majority of those depending $n n$ artificial regeneration stand on sedimentary formations.

The fact that greographical and climatic conditions of the country vary in different places as stated above is favorable to sise growth of various kinds of forest trees and the fact that the topographical and geological features of the country are also quite different in different places has caused a variety of forest growth to spring up. As it is, no less than eight hundred species and varieties of forest trees are found to be well suited for culture here. But at the 
present stage of the development of forest work in this country the ecunomy of forest management does not allow to attach any special importance to not more than ten or twelve species of forest trees.

Geographical Distribution of the Forests. - The forests of Japan are divided into four groups, viz:] Tropical forests,SubTropical forests, Temperate forests and Arctic forests.

Tropical Forests.-Tropical forests grow in the whole of Formosa, the southern half of Okinawa, the Yayeyama Group and and the Ogasawara Islands. From the standpoint of altitude these forests are found on Niitakayama in Formosa at places below 500 metres where the annual temperature does not fall below $21^{\circ} \mathrm{C}$.

Of the tropical flora the banyan heads the list followed by several species of palms and the bamboo. The banyan tree is represented by more than 18 species, all of which are found to be capable of luxuriant growth. But this and other tropical plants do. not furnish useful timber except the bamboo, several species of which are found in groves everywhere in these regions, growing with wonderful rapidity and producing huge canes, hard and strong, useful for manufacturing various kinds of utensils as well as for building purposes.

Sub-Tropical Forests.-The Sub-Tropical forest regions comprise a portion of Okinawa, the whole of Shikoku and Kyūshu and the part of Honshu lying south of $36^{\circ}$ N.L. With reference to altitude, places lying 1,900 metres above sea level in Formosa, helow 850 metres in Kyūshu and below 500 metres on Mt. Tsukuba in the province of Hitachi, Honshu, belong to this section, all these enjoying an average annual temperature oi $13-21^{\circ} \mathrm{C}$.

The Sub-Tropical trees are of numerous species and are highly valued in sylvicultural economy. As the better-known parts of Japan, the "beaten tracts" as the tourist would call them, "Japan unper" as the geographer would say, have a dense population and "arly developed industries, they do not now possess forests enough to meet the local demand for timber. As the result of continued reckless felling that has been going on in these regions for many years, there remain only a few forests preserving their primitive features, and in Honshu it might be said that there are no such forests except wichin the precincts of the Shinto or Buddhist temples. 
The sylvicultural characteristic of Sub-Tropical regions is that they are in possession of broad-leafed evergreens, but as the result of careles, cutting and conflagrations deciduous broad-leafed species and the red pine have made intrusions changing the sylran aspect to a remarkable degree. In accordance with the present features the forests in these regions have to be divided into three classes, broad-leafed evergreen, broadleafed deciduous and pine forests.

Trmber Trees in Sub-Tropical Forests.-The species of chief importance to the sylviculturist among the broad-leafed evergreen trees growing in this zone are no more than the undermentioned :-

Camphor Tree (Cinnamomum Camphore, Nees):-Being a native of this zone, the camphor tree grows in Shikoku, Kyūshu, Formosa and the province of $\mathrm{Kii}$ in Honshu. This species is sometimes found forming a big forest. It grows everywhere in this zone, if the soil is clayey and fertile, especially in places facing the south and free from cold winds. In Formosa it is found as high forest, either pure or mixed, up to the height of 1000 metres above the sea level. In Kyüshu, Shikoku and the southem provinces of Honshu, old and big trees of this species are found here and there, thanks to the time-honored custom of using them as ornamental groves of both Buddhist and Shinto temples. The timber is somewhat hard and lustrous and has a peculiar odor. It is prized for use in making valuable articles of furniture as well as for ornamental purposes. It lasts well in water and has been valued from ancient times in shipbuilding. In recent years the demand for it as material for the production of camphor valuable in the various branches of industry has very largely increased and forests have been planted both by the Government and by private persons.

Truge (Boxus Sempervirens, var. Japonica, Mak.):-This tree even in the largest sperimen measures not more than 50 centimetres in diameter and 15 metres in height. The timber is exceedingly hard and close and fine grained, so that the yearrings can hardly be distinguished. The inner wood is lustrous and pretty and is used not only in fine sculpture but in the 
making of valuable articles and nice rules and instruments because of its freedom from shrinkage or expansion, whether wet or dry. The tree grows in Kyūshu, Izu and other provinces, especially in the Kawara and Koshoyama State forests in Kyūshu and in the private forests in Mikura and Miyake islands in Izu. Is a shade-loving tree and grows well in calcareous soil. The young trees are liable to frost damage, hence they must be made to grow under protecting trees. Reproduction by means of planting young shoots or the insertion of sprigs.

Ubame-gashi (Quercus phyllireoides A. Gr.):-The several varieties of Kashi (oak) are the most widely distributed of the broad-leafed evergreens. The Ubame is found in the southern provinces of Honshū, in Awa, Kazusa and Shimōsa, in Kii and in the southern part of Shikoku. On the shores of Tosa and Kii, they are found growing in pure woods, but in other places mixed with other varieties of Kashi. The timber is white with a shade of yellow, is the hardest and heaviest of all timbers produced in Japan. Is used in house building where hardness and strength are required, but the chief use is in charcoal making. Considered as the best fuel wood in Japan.

Ichii-gashi (Quercus gilva, Bl.) : Shira-gashi (Quercus Vibrayeana. Fr.) : Aka-gashi (Quercus acuta, Thumb.) :-

These three species are the most extensively utilized of al [ broad-leafed trees. The timber closely resembles that of the Ubame-gashi; but its growth is quicker than the growth of trees of that speries. Is valued in the making of the handles of agrieultural and other tools and implements; also in making wheels and rudders. The Ichii is sometimes found growing so big as 55 centimetres in diametre and 30 metres in height, the bole measuring 15 metres. Under the old régime the wood of this tree was highly prized for handles of spears and in the several clans there were strict regulations forbidding the felling of treas of this species. Grows in Kyūshu, Shidoku and the southern provinces of Honshu. Pure woods are rare; found mixed with other species of Kashi. Very widely distriduteb; 
fond of shade and grows well under standard trees. This tree is reproduced either naturally or by planting.

The deciduous broad-leafed trees belonging to this zone are mostly found in planted woods, principal species being Kunugi, Konara and Shite.

Kunnegi (Quercus serrata, Bl.) :-This species ranks high among Japanese trees in affording excellent firewood; ranks next only to the oak for use in making charcoal, the far-famed Sakura and Ikeda charcoal being made from this wond. Not found in mountain regions. The home districts of these trees were limited to the neighborhood of the province of Settsu and a part of the Musashi plain. But the trees being easily made to form a coppice under a short-term rotation founded on very economical calculations, they are now fuut everywhere in the country planted as private property, except in the northern half of Houshu and the whole of Hokkaido. The bark contains tannin and is therefore used for dyeing purposes and in the curing of skins. The wood is also extensively used as logs for growing thereon Shiitake, an edible mushroom.

Konara (Quercus glandulifera, Bl.):-Also valued as a firewood and charcoal yielder and commands a large sale. Found as a principal tree in natural mixed forests in the hilly and mountainous districts of Honshu, covering immeuse tracts; also found in Hokkaidō. Like Kunugi it is somewhat fond of light and may grow in any land holding a suitable quantity of moisture within the temperate regions. It is coming into vogue for the maling of artificial coppices of this species of oak mixed with Kunugi, Shite and other trees.

The Pine fumily is represented by two species: Akamatsu or "Red pine" and Kuromatsu or "Black pine:"

Akamatsu, or "Red Pine" (Pinus densiflora, S. et Z.) :The most widely distributed of all the coniferous trees in Japan being found from the southern extremity of Kyushu to the southern portion of Hokkaidō; thrives in all soils except in places where more or less water always stagnates. Is fond of dry, nell-drained land yellowish or reddish in color. It takes possession of deforested areas before other kinds of 
forest-trees begin to grow. In the southern portion of Honshu it is found in excellent condition at the height of 2,000 metres above the sea. It demands light and hates shade. Forms splendid forests either by natural or artificial regeneration. Mostly found in pure woods; sometimes as mixed woods planted with the bamboo, Konara and other trees. Because of its hardy nature and speedy growth, communes, religious establishments and private persons are very fond of planting groves composed of these trees. In the southern and central portions of Honshu, where, in consequence of wanton felling, the soil has been grcatly impoverished, the red pine will come to occupy vast areas in the near future. The wood, which is yellowish white with a shade of red, is hard, strong and elastic and contains a large percentage of resinous substances, which makes it proof against moisture; hence prized for use in engineering works and as mining props. Used for building purposes though not nearly equal to Sugi and Hinoki in this respect. As firewood ranks among the most indispensable kinds of wood used for that purpose. The "pine mushroom" (Matsutake), king of table mushrooms, grows in the "red pine" forests in the southern part of Honshu.

Kuromatsu, or "Black Pine" (Pinus thenbergij, Parl.):-Like "red pine" it serves various purposes. The wood, of reddish c $\mathbf{c}$ lor, is strong and hard and contains a very large perecntage of resinous substances. Being very durable is suited for bridge foundations and for use in general earthwork engineering. As firewood, it is ralued as a great heat-producer! the root-rood being especially rich in resin is used as torches. Thrives well in sandy soils along the seashore. Found all along the coast of Shikoku, Kyushu and Honshu; the area covered very extensive.

Besides those we have groves of bamboos in the subtropical regions. Bamboos take rank among useful timbers of Japan. The chief species of bamboos cultivated are Madake, Hachilus and Mōsō.

Madrlie (Phyllostachys bambusoides, Sieb. et Z.) and Muchilin (Phyllostachys pubcrula, (Miq.) Munmo).-Mave beron used from ancient times for making various tools and uteusils and for 
building and ornamental purposes. Recently bamboo work began to be largely exported to Europe and the United States. Ex tensively cultivated by private persons in the southern part of Honshu, Shikoku and Kyūshu wise neighborhood of Kyoto aud Nara abound in splendid bamboo groves. At Yamashina, Kyoto, there are groves producing Madale canea measuring 22 contimetres in diameter and 22 metres in length. Bamboo groves are mostly found planted either between plots under cultur or on hill-sides. They are rarely of any considerable size. Bambin planting is fitted for sylviculturists with small capital.

Mōso (Phyllostachys mitis, Rivier):-The largest of the bamboo family; sometimes found of such dimensions as 30 centimetres in diameter and 25 metres in height. Planted in groves mostly in Kyushhu, Kii and the provinces adjacent to it. Valued for the manufucture of tools and utensils.

Tamprate Foristi.-The Temperate sylyan flora extend from the northern half of Honshu to the southern half of the Hokkaido, between $36^{\circ}$ and $430^{\circ} \mathrm{N}$. L., where the average annual temperatures range from $6^{\circ}$ to $13^{\circ} \mathrm{C}$. The Temperate forests rise in Formosa to the height of 3,500 metres: in Shikoku 1,800 metres; in Central Honshu a little lower, to wit, 1,500 metres; and in South Hokkaidē 500 metres.

These forests cover a large area and not a few of them maintain their primitive features. Being mostly natural woods of splendid trees they form the most important item of Japanese sylvan wealth. But as in these regions the climate gets rather cold and the snow lies on the ground during half the year, the trees are liable to be damaged by snow and require no small amount of tending and protection.

Thmer Trees in Temperate Forests.-The number of the species of trees belonging to these regions is over (60) lint the more important of them are Hinoki, Sugi, Hiba, Koya-maki, Sawara, Nezulio, Momi, Tsuga, Ira-momi, Bara-momi, Himetio-matsu, Chösenmatsu, Goyo-matsu and Kara-matsu in the Coniferous class; and Keyaki. Yachidemo, Katsura, Onara, Sau'c-gurumi, Tochi, Kurumi, Nire, Kuri, Kinada, Harikivi, Enju, Hakoyanagi, Doro, Hönokr, Kashiwa, Salura, Buna and Kaede in the Broul-Leafed class. 
Hinoki, Fir (Chamaecyparis obtusa, S. et Z.) :-The timber is soft, close-grained, strong and tough and has a peculiar scent. Ranks first among Japanese timber trees, being used for building purposes, and as an ornamental wood and in engineering work and naval architecture; also in bridgework. Grows in the southern half of Honshu, Kyūshu and Shikoku. In the provinces of Kii, Yamato, Musashi, Tōtōmi, and Tajima, we find extensive forests of this tree. The natural Hinoki forest in Kiso is one of the three best forests in Japan. The natural forests in the Koya mountains in Kii are noted for producing big Hinoki tree. The home of this tree is in the central portion of Honshū, in regions from 550 to 1,400 metres above the sea level, but where the atmosphere contains a suitable proportion of moisture, it is found in well-formed woods, either pure or mixed, in both higher or lower districts.

Hiba (Thujopsis dolabrata, S. et Z.) :-This tree together with Hinoki, Sawara, Nezuko and Koyamaki formed the so-called Goboku or "Five Trees" under the old régime and enjoyed careful protection at the hands of the feudal authorities. Mostly regenerated naturally; rarely planted. The Aomori districts in the north are noted for having pure woods of Hiba. The State forests in the Tsugaru and the Nambu peninsula are nearly pure woods of Hiba with a slight intermixture of Buna. There are extensive forests of Hiba mixed with other coniferous trees, such as Himeko-matsu and Sawara, in the mountains on the northern frontier of Rikuchū; in Goyosan in Rikuzen and in the mountains in the Tone districts, Kōzuke. The wood grows slowly and the year-rings are extremely narrow. The timber is compact and strong; therefore used for building and engineering purpose. It has lately come to be in great demand for use as railway sleepers, its durability being peerless.

Sugi (Cryptomeria japonica, Don.);-Very widely distributed, being second only to "Red pines" among the conifers in this respect. This tree wants light, grows well in soils having a suitable amount of moisture, is capable of spectly and considerable growth, some specimens being found of such huge dimensions as 2 metres in diameter and 40 metres high. In suitable soils 
and atmosphere this tree forms woods throughout Shikoku, Kyūshu and Honshu and even in the southern provinces of Hokkaidō. Splendid specimens of natural pure woods of Sugi are found in the Nagakizawa State forests in Akita, while specimens of artificial forests are seen in the private forests in the Yoshino districts in the province of Yamato. The natural forests in Yakujima in Kyūshu are celebrated for producing timbers having very fine and pretty grains known as Uzura-moku, partridge grains. The wood is light yellow with a shade of red; used very much like Hinoki for building and ornamental purposes and in the manufacture of tools and utensils.

Sawara (Chamecyparis pisifera, S. et Z.): Nezuko (Thuya japonica, Maxim.): Koya-Maki (Sciadopytis verticillata, S. et Z.) :-Naturally these trees are always found in mixed woocis, and never as pure woods. In Kiso and in the Koya mountains there are natural woods of these trees mixed with Hinoki and other coniferous species. They are also found in large groups in the provinces of Yamato, Bungo, Satsuma, Ömi, Iwashiro, Shimotsuke and Uzen, 900 metres to 1,800 metres above the sea-level. The timber of Sawara and Nezuko is of pretty appearance, but being soft, light and easy to split is mostly used as boards and planks by joiners and carpenters. The Küya-maki grows extremely slowly, its timber is close-grained and containing some resinous substances is very durable in water. It is therefore valued for making water-pails and for use in earthwork engineering.

Momi (Abias firma, S. et Z.) :-Quite widely distributed, being always found in the primitive mountain forests in the southern provinces of Honshu, Kyüshu and Shikoku. Is a shade-hearing species. After its middle age it grows very fast and in well-adopted soil forms perfect trunk. The timber is light and coarse and undergoes much expansion and contraction, therefore inferior to the timber of other conifers. Owing to the length of its tibres and the posibility of eleaning them hy bleaching, it is used almost exclusively as paper pulps. There being a great demand for the pulps the tree may gradially become extinct unless steps are taken for its artificial regenera- 
tion. The boxes and cases exported to foreign countries from Japan are mostly made of this wood.

Tsuga (Tsuga sieboldii, Carr.) :-In distribution similar to Momi and mostly found in woods mixed with Momi. Growth very slow; the timber being of compact structure is highly appreciated for ornamental purpose. Used like Momi as material for paper and box making.

Himeko-matsu (Pinus Parviflora, S. et Z.):-Is found in woods in regions between places elevated 1,600 metres above the sea on the Kōtsuke-Echigo boundary-line and the mountain ranges of Iwashiro. Nearly pure woods are seen in the provinces of Toshima and Shiribeshi, Hokkaidō.

Goyō-matsu (Pinus pentaphylla, Mayr.) and Chōsen-matsu (Pinus Koreinsis, S. et Z.) are found overlapping the Temperate regions and the Arctic. Barely met with in the mountains in the central and northern sections of Honshu. The Goyo-matsu is found in the form of a quasi-pure forest in the province of Tokachi, Hokkaidō.

Bara-momi (Picea polita, Carr.) and Ira-momi (Picea bicolos, Mayr.) are very limited in distribution being only found to any great extent on the sides of Mount Fuji, at the height of over 2,000 metres above the sea-level. Generally they are found in solitary clusters on the high mountains. As they possess the useful characteristic of making reasonable growth even in poor and shaded land, they have drawn the attention of the Government authorities as being probably suited for making protection forests intended to preserve the soil. The growth is very slow and the timber being very soft, is inferior to that of other coniferous species for ordinary purposes hut is suited for making ceilings and also water-free articles of furniture.

Kara-matsu (Larix leptolepis, Gord.).-Found in natural woods at Mts. Fuji and Asama and the Azumi districts in the province of Shinano. Grows wild in the mountains of Nikkō; nowhere elso found in natural woorls. It is a decidedly light-demanding species and thrives in dry soils of volcanic grigin. The timber is tolerably hard and dumable and valued for house and ship-building purposes, as telegraph poles, in civil engine- 
ering work and for other uses. The tree grows fast and is free from ordinary dangers incidental to sylviculture. Thrives well in any soil however poor, hence it is growing in popularity in Honshu and Hokkaidō.

The broad-leafed trees of the Temperate regions are very numerous and occupy more than one half the area under forest. They are found everywhere in great luxuriance, but single species are rarely seen in the form of a strictly pure forest, although Konara, Kashiva, Onara, Kaba, Doro-no-ki, Han-no-ki, Katsura and Buna are widely distributed throughout Honshu and in the southern half of Hokkaido in almost unmixed woods. All the other species grow in irrogular intermixture with other broad-leafed or needle-leafed trees, sheltering and protecting each other so as to preserve the original sylvan features. Below are given chief species of sylvicultural importance:

Keyaki (Zelkowa Keaki, Sieb.).- No other broad-leafed species is adopted to so many ways of utilization and so highly valued as Keyaki. This species is found everywhere in Honshu, Shikoku and Kyūshu, but rarely in pure woods. It grows to enormous dimensions in woods intermixed with shade-bearing species of the broad-leafed family. Loves calcareous soils and the south-eastern sides of mountains, where, when the soil is suitable, it attains perfect growth. Found wild below 1,600 metres in Shikoku and Kyüshu and under 750 metres in the northern section of Honshu. Kiso, Izu, Tōtōmi, Kii, Hyuga, Yamato, Ise and Ōu (the north-eastern districts of the Main Island) are especiall noted for producing big Keyaki trees. Requiring a great many years for its full growth, it is unsuited for planting hy private sylviculturists with small capital. The Government is, however, making their best endeavors to preserve and increase the areas under this species. The timber is very strong, hard, and lustrous; highly valued for building and ornamental purpose; also in naval architecture. Keyaki timber which has Jorin (ring-like), Uzura, (partridge feather), Tama (gem) or Boten (peony) grain is used for making valuable articles of furniture. Keyaki wood is a favorite material for sculptors, being hard and easy to work. 
Buna (Fagus sylvatica, var. Sieb., Maxim.)--Occupies the largest space next to Akamatsu. Found in the hills and mountains in the northern section of Honshu, in the elevated districts in the southern section of Honshu, Shikoku and Kyūshu; also in many provinces of Hokkaido. Mostly found mixed with Onara, Katsura, Shioji, Itaya-Kayede and other trees, but in Aomori, Iwate, Echigo and Yamagata pure woods of vast dimensions are seen in the mountains over 300 metres above the sea. As a firewood and charcoal producer, this is one of the most important speces. The timber is little used for building purposes. The Kosaka, Ani and other mines have large Buna forests for getting supplies of fuel. This tree grows well in the shade and having the characteristic of growing even when extremely old, it sometimes attains an enormous size. The Ainos in Old Japan are said to have made log-boats of this tree.

Yachidaino (Fraxinus mandshurica, Rupr.) and Katsura (Cercidiphyllum japonicum, S. et Z.,).-The only broad-leafed species affording building timbers. Also used for ornamental purposes. Very widely distributed, found in all parts of Hokkaidō and in the mountain valleys in the northern section of Honshu. Thrives best in level ground; excellent pure woods of Katsura are seen in the province of Iburi. The timber is soft and compact and possesses elastic powers of a durable character. Hence extensively used of late as railway sleepers; it is chiefly such sleepers that are exported to North China.

Inu-Enju (Cladrastis amurensis, var. floribunda, Maxim.):Found in the northern section of Honshu and in South Hokkaido mixed with other broad-leafed species. The timber is very pretty and is used for making valuable articles of furniture. Exported to China and Korea as railway sleepers.

Kurumi (Juglans sieboldiana, Maxim.):-Grows in rich mountain valleys and on low lands in the central and northern sections of Honshu. On the plains of Ishikari and Tokachi in Hokkaido, it is found in woods mixed with Yachidamo, Katsura, Nire and other trees. The timber is in demand for making railway carriages and for highly ornamental purposes, and also for rifle-stocks. 
Harikiri (Acanthopanox ricinifolium, S. et Z.):-Grows in wet soils in Shimozuke, Iwashiro and Iwate; and everywhere in Hokkaidō. In rich soil attains considerable dimensions. The timber is somewhat hard and lustrous with well defined grain and whitish in color. Prized for ornamental purposes and for making articles of household furniture. In great demand as railways sleepers like Yaciidamo and Katsura.

Kashiwa (Quercus dentata, Thumb.) and Onara (Quercus crispula, Bl.):-Found in wet places between the mountains in the Nasu and Ōu districts in Honshu and everywhere on the plains of Hokkaido. In Honshu rarely found in pure woods, always growing mixed with other broad-leaf species, but in some parts of Hokkaido, there are extensive pure woods of these trees The timber of Onara is widely used as sleepers and is one of best producers of firewood and charcoal. Kashiva contains tannin in its bark and is used in curing skins. Otherwise it is not used, except as firewood.

Hako-yanagi (Populus tremula L. var. villosa, Mesm.) and "Doronoki" (Populus balsamifera, L. var. suaveolenus, Loud):

The two species are most valuable wood in Japan for making match-sticks. The former grows all over Shikoku, Kyüshu, Honshu, and as far north as Hokkaido, while the latter thrives well in the north-eastern districts of Honshu and Hokkaidō. They grow easily in sandy wet soil, are found forming uniform forests of perfect sylvicultural aspect in many parts of Hokkaido. The trees are fond of light and under favorable condition Sheir growth is very rapid, and after 25 years from germination they easily attain the height of 20 metres. Reproduced by seeds or layer or by dividing the roots. They are being planted extensively in private forests.

Kuri (Castenea vulgaris, var. Japonica, D.C.) :-The extent of the growth of this species is exceedingly wide. In Kyusshu and Shikoku and the western parts of Honshu the tree imparts a special aspect to the forests growing on the sides of high hills or on hillocks. In places north to the middle section of Honshū, it grows well on the plains and produces valuable timber. However the specie rarely forms any extensive pure 
forest of its own, and generally mixed Buna, Hiba, Kiwada, Katsura, Kayede Savakurumi, etc. In the Kobinata State forest found in Tone district, Kōzuke, and in Hiraga district, Ugo, it is found forming pure forests of no small extent. The timber is extremely hard, can stand wet, and on the whole lasts long, is therefore preferred for railway sleepers to any other tree growing in Japan. The sleepers used in the Government Tôkaido railroad and in the Hankaku railroad are made from the timber of this tree.

Sakura (Prunus pseudo-cerasus, Lindl. var. spontanea Maxim), Kaede (Acer palmatum Thurab. var. Mono Max.), Honoki (Magnolia hypoleuca, S. et Z.) :-These are not trees of any great sylvicultural importance, and very rarely do they form pure forests of their own, growing mostly, as they do, amidst conifers or broad-leaf trees. However they are of importance for certain special purpose, and as the supply is hardly sufficient to meet demand, their price is comparatively high. In view of this fact, both in State forests and private forests, they are being planted side by side with trees of other sorts,

Tochi (\&sculus turbinata, Bl.), Nire (Ulmus campestris, var. Leavis, Planch), Hannoki (Alnus japonica, S. et Z.), Toneriko (Fraxinus Bungeana, DC.), Saikachi (Gleditchia japonica, Miq.), Yanagi (Salix Species) are deciduous broad-leafed trees not particularly possessing any great sylvicultural value. They are grown in this zone for the purpose of giving protection to primary trees or for maintaining the fertility of forestland.

Frigid Forests.-Forests in the Frigid zone occupy in the northern half of Hokkaido and the Kuriles those places where the average yearly temperature does not exceed $6^{\circ}$. In regard to altitude distribution, the zone comprises in Formosa those places that are not less than 3,500 metres from the sea-level, and in the middle section of Honshu all places 1,800 metres above sea level.

Timier-treas in Frigid Forrests.-Timber-trees growing in this region are naturally not so numerous as in those in warmer regions. Indeed as the forests of this zone, except those in Hokkaido, are located in high altitudes, with fror soil, and subjected to strong 
win is, the trees are generally too stunted in growth to be of any value.

In Hokkaido, however, conifers grow luxuriantly and many primitive forests not yet explored are found. The principal trees in these forests are Todo-matsu (Abies Sachaliensis, Mast.) and Yezo-matsu (Picea ajanensis, Fisch.). Starting from altitudes measuring 450 metres in the southern parts of the island, these trees are found growing luxuriantly in the mountains of Ishikari, 'Teshio, Tokachi, Nemuro, and Kitami, and lastly in the island of Kunajiri. The Imperial forests at Tarunai, Uryu, Kushiro, and the State forests at Otoneton, Shari and Kunajiri practically consist of extensive pure forests of these trees, presenting a highly regular aspect. The timber of Todo-matsu is in large demand for architectural and earth-works, and is indeed most valuable of all the timbers produced in Hokkaido. The wood is, however, coarse-grained, and light and is liable to bend when exposed alternately to dryness and humidity. Rather close-grained and resinous, the wood is in great demand for architectural work.

Akaezo-matsu (Picea Glehni, Mast.).-Though valuable as timber next to the two foregoing species, this tree rarely forms a pure forest, is in greater denand than the other two, and commands a high price. The wood is close-grained and suiterl for architectural work.

In Etrup and Shikotan of the Kuriles, a species of larch, scientifically termed Larix dahurica, var. japonica, Max. is found growing, and exposed to inclement climate forms a pure forest of good aspect. The wood is reddish, hard, and well stands wet, and is therefore used in shipbuilding, earthwork and furnituremaking.

Shira-kaba (Betula alba, L. var. vulgaris, DC.), Yama-hennoki (Alnus incana, Willd. var. glauca, Ait.), Nanakamailo (Pirus aucuparia, Gaeten. var. japonica, Max.) are some of the deciduous broad-leafed trees that are found in this zone either as pure forests or scattered among other trees. They are, however, of small sylvicultural value, and are generally used as firewood by miners or fishermen residing in the vicinity. 
There are many other trees growing in the respective zones, but the principal species are generally confined to those above described. As found in natural growth, they either form pure forests or are mixed with other trees. In general conifers occupy in the southern districts elevated places, while forests on the level mostly consist of broad-leafed trees. In the northern districts conifers cover mountain slopes, while on their top and foot broad-leafed trees predominate.

Ratio OF DIFFerent kiNdS OF WoOded-AREAS.-On the whole the different classes of forests exist in the following proportions in the wooded areas of Japan:-

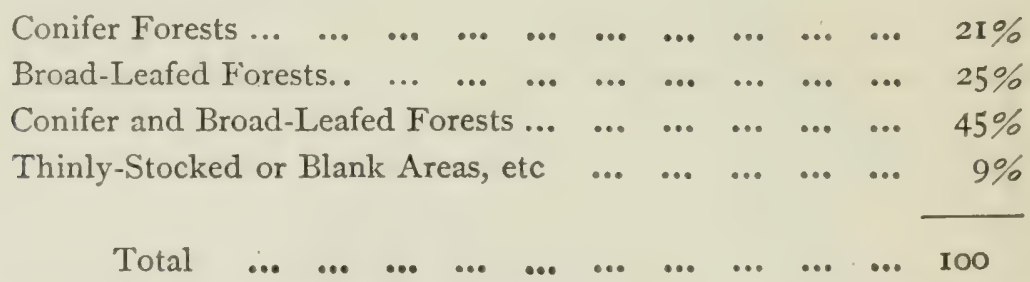

Bamboo areas, though forming a feature in our forest system and sufficiently profitable in exploitation, are still extremely limited in extent; nor do they show any sign of enlargement in a near future. A description of them has, therefore, been omitted here.

The growing extension of $A k a-m a t s u$ forests recently in Honshu, Shikoku and Kyūshu tended to raise the relative ratio of conifer forests to broad-leafed forests, and this tendency is further accelerated by the greater demand, in consequence of the development of industry and business, for such conifers as Sugi, Hinoli, and Iicuramatsu, which are being planted extensively. In the State forests the relative proportion of the different kinds of forests stands as follows:-

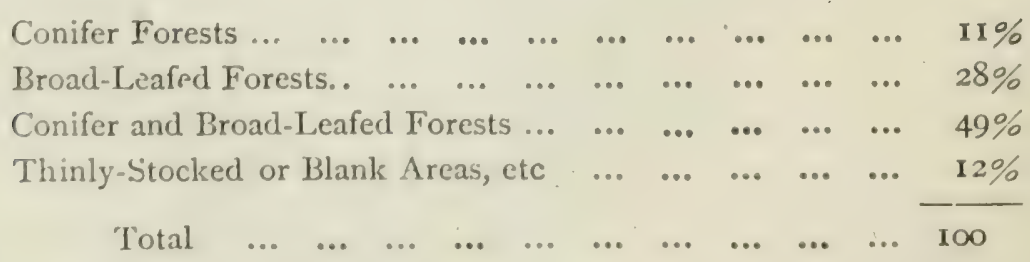

The forest-areas devoted to conifers will attain before long the proper ratio to which they are entitled from increasing demand upon them. 
In the Imperial forests, owing to the greater attention paid to forest aspect, the relative proportion is more satisfactory, as :-

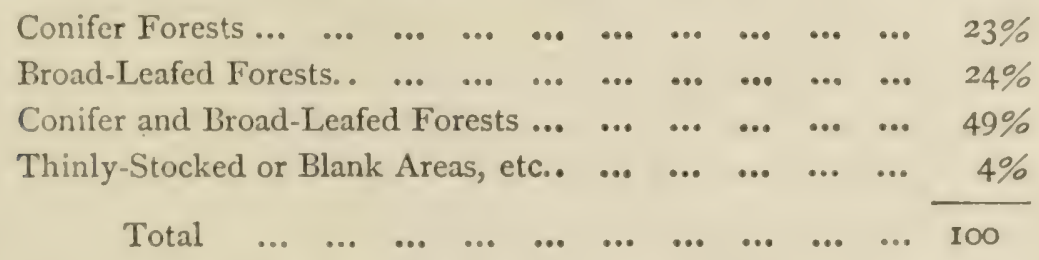

Both in the State forests or Imperial forests the principal trees are, in ennifers, Aka-matsu, Tsuga, Todo-matsu, Sugi, Hinoki, Momi, etc.; while, in broad-leafed trees Buna, different varieties of Nara and Kashi, Kaba, Kuri, etc. constitute principal species.

\section{ADJUSTMENT OF THE FORESTS.}

General Remarks.-The work of forest adjustment was attended to by the Court as early as the Konin era (the beginning of the 9th century), when the Emperor of the day issued a proclamation restrioting the undue felling of trees and ordering in general the due protection of forests. From about that time till the advent of the Tokugawa Regency, the sylvicultural business fared no better than other industrial affairs, that is, it suffered much from neglect and devastation. With the establishment of the Tokugawa régime, and after alout three centuries of this iron administration something like a regular system for protection of forests had been evolved. Different systems prevailed, indeed, in different daimyiates but they all had this feature in common, that is to say they originated from necessity of military defense. Stern rules characteristic of a military despotism were therefore enforced for the protection of the forests. It is true that even then forests were divided into utilization forests and protection forests, but even in the case of the former more or less severe restrictions were always enforced. The existence of protection forests was extraordinary both in kind and extent. These comprised forests at the headwaters of rivers, the forests planted to prevent landslips, the forests planted to protect against damage from heavy snowfalls, the forests intended to give shelter to the 
water and to invite the collection of fish in it, and forests of other lescriptions. For the protection of special kinds of trees the rules enforced were extremely strict. The prohibition trees differed according to places. Hiba tree was protected in Aomori, "Prohibition Sugi in Akita, while Kiso had "five prohibition trees" Trees." Kii "six," Awa "seven" and Kumamoto "three." This prohibitive treatment gave rise to the development of the work of utilization and adjustment, and by keeping careful furest records and by adopting a conscientious system of rotation each daimyiate made it a point to secure the constant supply of valuable kinds of timber within its own borders. Whatever udvantages Japan now enjoys in the matter of forests, she must be said to owe to this jealous guard kept over her forests of old by the feudal pinces.

The protection of the forests having been maintained by despotic rules as was the case in France before the Revolution,-rules which did not originate in any regular economic principles, The Restoration the withdrawal of those rules on the Restoration was and the consequence. The Meiji Government lost no time, Deforestation. however, in taking measures calculated to check this alarming state of affairs. Those measures were, however, not quite calculated to cope with the trouble, and at best could but partially remove it. One of the most serious inconveniences that confronted the Forest authorities was the absence of definite boundaries between one State forest and another or hetween a State forest and a private forest, so that while in the former (ase the accurate determination of forest areas was not possible, in the latter case the State frequentiy claimed forests bolonging to the other owners. Again illicit felling or felling due to mistake frequently trok place, thereby complieating indescribably the work of proper control. It was primarily with the object of removing this frnitful source of trouble and of thoroughly adjusting the houndaries, that the authorities started in 1890 the first regular programme of treatment.

Finst Anfoustment Programul-This programme is to be completed in 15 years ending 1904. To meet the expense necessary for carrying it out the Governinent decided to disburse, besides 
recular expense, a sum of 855,851 yen on account of extraordinary expense. The programme aims in accomplishing the following object:-

1. To inquire into the condition of those State forests and plains (measuring altogether 6,600,000 cho) irregularly scattered over the country, to carefully classify them into those that should with benefit be maintained as State property and those that should be transferred to private property; also to elearly define the jurisdiction limit of supervising offices by determining the relative convenience of control and relative economic advantages.

2. To clearly define the boundary between State forests and to provide against illicit felling and felling by mistake.

3. To ascertain the exact area of those State forests of greatest economic importance measuring $1,380,000$ cho and to prepare accurate forest maps.

From its very nature the work embodied in the foregoing clauses requires a long space of time, but at the same time the elaboration of a definite sylvicultural system demands the speedy completion of the work. It was a very judicious measure, therefire, on the part of the authorities that the programme was adopted as a continuation work so as to preclude it from being altered by any new arrangement that might be made in future.

The working of this programme, which is to be completed this: fiscal year, has been highly satisfactory and has imparted for the first time a firm basis of operation to Government forestry policy. Thie sale of State forests and plains, the opening up of some of them to exploitation by private individuals either by being brought under cultivation or converted into pastures, the elaboration of a high rotation system for other kinds of forest-land-all these and many other things are the fruit of this work of the first programme, which may therefore be said to have inaugurated a new era in the economy of State forests in this country.

Second Adjesment Programme-The work started by that programme has been continued by the so-called second programme which eame into operation in 1898 to extend till 1943, a Special Forest Account Fund being created for the purpose. The work aimed at in this new programme is one of the highest importance, 
being nothing less than the adjustment of the irregular condition of State forests, the expansion of the limit of exploitation, the increase of fertility of forest-land, in short the thorough re-adjustment from the very basis of the economic system of State forests. Started in a concreate form the work involved in this programme consists in determining the forests and plains that may no longer be kept as State property, in the final survey of State forests and plains which should be kept as such, and in the elaboration of plan for working such forests and plains, planting open spaces, undertaking engineering works relating to forests, purchasing such forests as are required, and in short all those matters necessary for determining the system of exploiting State forests and plains. . The fund devoted for completing this programme was fixed at $23,025,053$ yen. The fact that the programme involved such a big outlay at first deterred the authorities from adopting it, but the difficulty was solved by setting it apart as a special account with the revenue supplied by the proceeds of the sale of forests and plains which may no longer be kept as State property. The measure embodying this programme obtained the approval of the Imperial Diet and was finally issued as law in 1898.

The completion of this important programme mainly depending on the sale of unimportant State forests and plains, it is evident that the authorities must carefully regulate this sale so that all the different undertakings in the programme may be regularly carried out according to the prescribed plan of operation.

- Financial Prospect of the Adjustment.-The result of the programme will revolutionize the economy of the State forests. Not to speak of an addition of 50,983 yen to the Revenue on account of the Land Tix accruing from the forests and plains tran-jicred to private owner:hip, the adjustment effected will considerably dininish the managing expenses and will improve the efficiency of the work of control. The revenue from the increased felling if erpecially important, it being estimated that after 1910 the revenue will be four times what it is now. This means an addition of oper 3,310,000 yen to the State Revenue. After the lapse of one hundred years, by which time the renovated forests, even supposing that the market price will remain as low as it in 
now, will have grown to 66 million yen a year, about a quarter of the total amount of Revenue to-day. That this forecast is by no means a sanguine one is proved by the experience of the four years that have elapsed since the commencement of the programme.

Investigation and adjustinent of State Forests.-The investigation was carried out from 1890 to 1894 into the existing condition of State forests in Shikoku, Kyūshu and Honshu where there are 719,473 such forests, with the object of selecting those forests which should be kept as State property and those which may with advantage be sold to private individuals.

Mode of First Adjustment plan.-The selection is made by keeping the following points in view :-

1. Those which exist in a lot of over 50 cho or in different lots found within the limit of one town or village or within the distance of not more than $2 \mathrm{ri}$ from each other, and which can permanently carry out independent sylvicultural work.

2. Those which exist in a lot of less than 50 cho but which can without any trouble be managed in consequence of the existence in the same district or in a neighboring district of a State forest or forests measuring over thousands or hundreds of cho.

3. Those which, though existing in a lot of less than 10 cho or are economically unimportant, are useful for constructing forest-roads, for the transport of wood or for storing wood, building official residences of foresters or for other matters connected with State forests.

The forests coming under any of the foregoing conditions were to be reserved as State property, and the others not satisfying them to be dispred of. Also forests or plains necentity to the farmers living in the neighborhood for getting fodder or trats for manure wore to be transferred to private ownership, provided no particular necessity existed for keeping them as State prinerty.

The resilt of investigation was that of the State forests and plains measuring altogether $8,095,916$ cho, $7,354,343$ cho were judged fit to he retained as State property and the remaining 741,573 cho unfit for that purpose. 
The proceeds obtained by disposing of those unimportant forests and plains are to be used as funds for carrying out the second forestry programme, mentioned above, that is to say, the forest exploitation as work of special account.

Second Adjustment Plan.-However the selection made was afterward judged to be not entirely satisfactory; it was found in fact to be satisfactory both in respect of omission and of commission, while with the progress of the times, it became necessary to take into a greater considerations than before the question of the public peace and order. It was decided in 1899 to make thorough second investigations based on advanced principles of forest exploitation. The rules to guide the investigation were drawn up and the work was started afresh in that year. The disposal of unimportant forests and plains determined by the second investigation is to be completed in six years from 1899, and during the three years from that year to 1901 inclusive about 51,756 cho in 16,113 lots were sold, and a sum of $5,199,198$ yen was realized by that transaction.

Demarkation of Boundaries and measuremext of State Forests And Plans. - The exact measurement of forests and accurate forest-maps being absolutely indispensable for conducting scientiffic treatment of forests, the Government issued in 1884 Notes relating to Boundaries of State forests, aud caused the local offices to undertake the demarkation of the boundaries and the measurements of the forests. The formulæ set forth in the Notes were too simple to render the result of the work to be of any great use. They were repeatedly improved, the last in 1899, and the system elaborated in the latter year is now in force.

TIIE SYSTEM Now IN FORCE.-That system divides the work into three divisions, vi\%, demarkation of boundiries, triangular surveying as applied to forests, and contour surveying. On the completion of the work, foundation maps of working plan are to be drawn on a scale of $1 / 5000$.

The final survey carried out according to the foregoing system rateledel in extent to 29,289 kilometres and $761,: 349$ cho :3 tun 5.22 *f in meanrement, There remain 2,850 kilometres for which the work of antour surveying has been accomplished but whose measurement still remains to be completed. 
Elaboration of the Working Pran.-The treatment of forests without any definite plan being inconsistent with the interest. of forest economy in 1890 a provisional working plan was therefore drawn up intended to provide some directions with regard tw felling. But with the progress of the first adjustment programme it was possible to apply a more scientific and permanent plan, at leart in the case of these forests for which the work of adjustment had been completed. The forests qualified to be dealt with under this permanent plan were those in Ehime, Fukuoka, Kagoshima, Hiroshima, Osaka, Ishikawa, Akita, and a few others. The notes drawn up for forming the plan were to this effect:-

1. That the system of sylviculture should be maintained in as perfect a condition as possible and that the utmost quantity of timber possible should at the same time be obtained.

2. That a proper care should be exercised in planting and felling, and provisions should be made against damage of wind and fire and insects.

3. That reserves should be provided to counteract the diminution of the crop incidental to such damage.

In the elaboration of the plan a minor forestry office was regarded as a unit of economy, and the determination of a yearly cutting volume was based on the area to be cleared and the crop to be obtained. With the progress of the work of adjustment and the greater light bestowed, in cousequence, on the condition of the forest., it was possible, especially as a result of the development of facilities of communication, to draw up a plan of a more perfect description. In 1899 and again in 1901 the necessary amendment was effected in the principle of the working plan. The amendment was chiefly intended to adopt the plan as well as possible to the conditions of a district and of a forest. It was also deeided that the improvement of the irregular aspect of the forests should be made in a limited space of time. In short, the plan was made to cover all matter:s relating to the utilization of timber and the renovation and regeneration of forests, and was intended to procure the maximum income and produce crops best calculated to satisfy the demand on the market. 
The permanent working plan as at first elaborated was first put into operation in 1893 and 58,916 cho $5 \tan 9$ se was adjusted till 1899, while from the time of the carrying in effect of the second adjustment programme to the end of 1901 the forests measuring 30,945 cho $7 \frac{1}{2}$ tan received similar treatment, making altogether 89,862 cho $3 \frac{1}{2}$ tan.

Adjustiment of the Imperial Forests. - The Imperial forests having been originally transferred from State forests, the conditions requiring adjustment and the elaboration of working plan were practically identical with those of the State forests. As in the case of State forests, therefore, the work of selecting those forests to be retained and those to be disposed of was started in 1892 and completed in 1898 while work of drawing up permanent working plan was commenced in the latter year. The final survey was carried during the nine years ended 1901 for forests extending in aggregate length to 7,076 kilou etres and measuring altogether 332,482 cho 2.21 se. The working plan for 147,205 cho in the forests at Fuji, Kiso, Amaki, and Watarae has been completed.

\section{IY. EXPLOITATION AND TREATMENT OF THE FORESTS.}

Sylvicultural Treatment and Ownership.-The working plan and economy of forests differ according as they are owned by private individuals, by the State or by the Imperial Household, for it is naturally expected that, in the forests belonging to the State or to the Imperial Household, the interests of the public and of the nation should be consulted more than in private forests. Consequently the managers of the State forests do not look for speedy returns. In view of this consideration the State and Household forests have elaborated a high forest system and the felling of trees is regulated according to this special system.

Forests also present a different appearance according as they belong to the State, to the Imperial Hous or or to private individuals. Thrse belonging to the former two are generally re- 
newed as a result of natural growth and are therefore less uniform in composition than those owned by people whose forests receive greater care, the object being to make them yield returns more quickly. The woods at Tókaido, already mentioned and thuse at Muro and Kii, are noteworthy in this respect, the profit derived from them being even larger than the rate in Saxony, where forestry is carried on to greater perfection than anywhere else throughout the world. On the other hand, Rotation in State affected by this consideration of obtaining quicker and Imperial returns, privately owned forests do not generally Forests. admit of high forest treatment. The State or Household forests are therefore obliged to supply that in which the other forests are deficient and to produce timbertrees and to properly regulate the cutting period. This period is generally as follows for valuable timber-trees:-

years.

\begin{tabular}{|c|c|c|c|c|c|c|c|c|c|c|c|}
\hline raj & •• & & 0 & & "• & •• & •.e & ・. & ・.・ & ・・ & \\
\hline finoki ... & $\cdots$ & ... & & & & . & & & & & 100 \\
\hline$i t a$ & ... & $\cdots$ & & $\bullet$ & & & •.・ & & "• & & \\
\hline 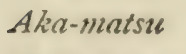 & $\ldots$ & ... & - & ... & ・. & .. & ... & & ... & & $40-$ \\
\hline & ... & ... & •. & ... & • & .. & & & & & \\
\hline & & $\bullet$ & & & & & & & & & $80-$ \\
\hline 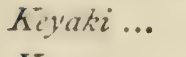 & & & & & & & & & & & $150-20$ \\
\hline & & . & & & & & & & & & $150-20$ \\
\hline
\end{tabular}

As the economy of ordinary forests does not admit of such high rotation, some of them adopt the medium Rotation in Pri- rotation system, such as coppice-with-standarl vate Foreste. systems, and while utilizing the underwood in it comparatively short space of time they leave the over-wood for utilization after it has reached the period of proper maturity. Sometimes the two-storied high forest system is adopted, and by planting light-demanding trees of quicker growth double rotation system is applied.

Forkst Formatioxs. - In regard to the selection of forestry formatiołs, considerable care is required, for while naturally regenerated forests require reorganization on account of their irregular aspect a pure forest formation is likely to cause trouble in Japau 
from wind or snow and also on account of the risks from injurious insects. The result is that the planting, as it is carried on nowa-days, aims at growing two or three different species made to occupy different compartments or groups or suitably mixed together. Then again the sylvicultural system as adopted in State forests necessarily differs from that in privately-owned forests, and varies also according to locality. For instance, on mountain slopes clear cutting methods, especially of any wide area, may be inadvisable and selection cutting and shelter-wood system have to be adopted. This selection cutting being, however, inconvenient, the Government is determined to adopt, as far as circumstances permit, the clear cutting method and to entirely renovate sylvicultural formation.

The coppice-with-standard system is adopted for a special sort of forestry management, especially for small fire-wood areas worked by private individuals who are aiming at the largest possible returns at within shortest possible periods. This system is of course out of place for a forest of any extensive. area.

Bamboo plantations constitute peculiar feature of our sylviculture, and is likely to prove highly profitable owing to the growing demand for bamboos. One serious drawback in the management of bamboo groves is the fact that land suited for raising any large bamboo forest is not to be found in Japan, while the more valuable varieties of this species can only be grown in certain limited parts of the country.

Coppice woods are grown to supply firewood, the demand for which is unusually large in Japan. 'They are generally left to. renew themselves, especially when the area is extensive; but those ituated in the vicinity of cities and towns are artificially tended, the species chosen for this purpose being senerally Kunugi and Konara.

The treatment of protection forest consists of selection cutting, the style of which must differ abcording to Selection Cutting in the character of the forest and to local condiProtection Forests. tions. The rotation should be regulated according to the following standards:- 
Copice Woods ... ... ... ... Not less than ro years.

Bamboo Woods ... ... ... ... Not less than 3 years.

Coppice-with-Standards $\ldots . .\left\{\begin{array}{l}\text { Overwood not less than } 30 \text { years, under- } \\ \text { wood not less than yo years. }\end{array}\right.$

Timber Forests ... ... .... ... Not less than 30 years.

Treatment of State Forests.-The total area of the furests under regular treatment is being ascertained at present by the Government. At present the data for State forests alone are available, these roughly standing as follows:-

Method of treatment.

per cent.

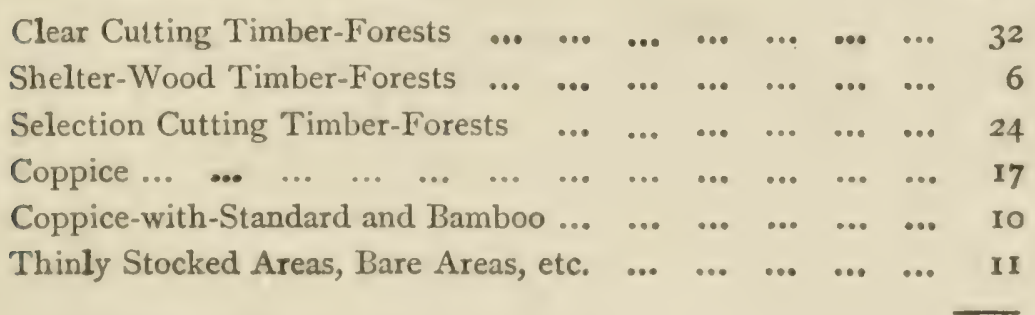

$\begin{array}{lllllllllllll}\text { Total } & \ldots & \ldots & \ldots & \ldots & \ldots & \ldots & \ldots & \ldots & \ldots & \ldots & \ldots & 100\end{array}$

It will be seen from the above that the timber-forests treatment occupies about 62 per cent. of the whole areas of State for $:-$ t. The principal growing stock consists of Buna (beech) 30 per cent.. Akamatsu 20 per cent., Sugi 12 per cent., Hinoki 7 per cent., Kushi (oaks) 6 per cent., Kuromatsu and Hiba, both 4 per cent., the remaining 17 per cent., cansisting of conifers and broad-leafed trees. In coppice woods Kumugi, Konara, and oaks occupy about 8.5 per: cent. while in coppice-in-standard woods Momi, Tsuga, oak and Nara predominate over any other species.

Conversion of WooD.-The method of conversion of wood have become more and more uniform than ever. There are usually three methods, these being the outcome of customs at different forest districts and in different markets.

Strues of Conversion. - The Fukagawa timber yard in Tokyo is the most important depot for the wood produced at the northern parts of Midelle Honshu. Three different styles of designation are in vogue in this depot corresponding to so many moles of convertion. These are "Motoki," "Nami-motoki" and "Kawabe-mono." The first comes from the wood districts of Mino, Hida, Owari, Tōtōmi, 
Tosa, Mikawa, etc., with a standard length of not less than 14 shaku, the second is applied to woods coming from Kii and measures not less than 14 shaku, and the last one is applied to woods produced at Hitachi, Shimozuke, and Musashi with the length of 14 shaku. Woods coming from Hokkaido and the north-eastern parts of Honshu a:e treated as "Motoki" and therefore possess measure of corresponding length. All these kinds of timber are prepared either as round logs or balks or sawn timbers. The converted timbers of "Motoki" are required to posiess the legal standard, but for those of the other two kinds the allowance of 2 to 3 per cent. to the standard measure is concecied.

In general Sugi, Hinoki, 'Matsu, Keyaki, Momi, Tsuga, Hiba, Yachidamo, Hōnoki, hatsura, etc., are converted as sided logs, while Ślgi, Hinoki, Saraia, Tochi, etc., appear on the market as round logs.

SEAson of FEllixt.-The season of felling depends of course upon the local conditions, the convenience of transport, etc. but in general the five months befiming with the autumnal equinox and ending with the succeeding February are regarded as the felling season. In such snowy regions as Hokkaido and the northeastern districts of Honshu where the means of transport are imperfect, felling must be started in the beginning of the snowy season, so that the timber may be easily carried over the snow. In places where the supply of timber for industrial purposes or firewood is to be kept up all the year round there are arrangements for the uninterrupted felling of the trees.

Transport of Converted Wood.-The transport of converted timber may be divided into two stages, the first being the transport of woods from felling places to depots and the second the transport of the timber from the depots to the markets. In the first stage, chicfly owing to the hilly condition of the forest area in Japan and also to the presence in its proximity of rivers and streams, water ways have been ntilized from early times for the conveyance of timber. Indeed econmini: considerations do not yet allow in most cases the contruction of special forest roads. Transport of timber along the midrle and lower courses of rivers is generally, as in Bangkok and Rangoon, in the shape of rafts, till the timber reaches depots usually 
situated at the mouths of the rivers and therefore easily accessible from the sea.

The facilities supplied by rivers are attended in Japan by a drawback usually unknown in other countries, and that is by the necessity of suspending the river transport during the season of the planting and growth of the ricc-plant, when the water of rivers is extensively utilized for the purpose of irrigating the rice-fields. Then there is another drawnback in this system, for the distance between the source and mouth of our rivers being comparatively short they are liable to become suddenly overflown in time of heavy rain. Therefore the river transport of timbers is generally done during the seven months elapsing between the season of the autumnal equinox and that of the spring equinox.

However in consequence of the recent increasing demand for timber and also owing to the extraordinary improvement in the means of communications, coupled with the consideration that rivertransport, besides being attended by the drawnbacks before mentioned, is liable to injure the quality of the timber, the tendency has gradually set in of making arrangements for land-transport and of constructing forest roads leading either to railroads or high roads. These arrangenents are being made in State forests, and the result has proved economically profitable.

Mrnor Forest Proptce.-The tenaency to a luxuriant undergrowth in Japanese forests, principally due to abundance of moisture, gives the minor produce business a peculiar aspect, for the removal of the undergrowth is of course necessary for the sake of the forest as for that of the undergrowth if the latter is to be utilized as a minor produce.

Litrens.- In forests belonging to the State or in those kept in its custody the people living in the vicinity are generally allowed, under certain conditions, to collect gratis dead branches and leaves to be used as fuel.

Grasses and Herbage.-Though not so extensive as formerly, the custom still prevails among our people of regarding forests and woodlands as places for getting fuel and fertilizers in the shape of grasses and herbage, so that even at present there is no small number of woodlands containing no growing stock and principally 
used by the people for procuring manure grasses and herbage from. It is in those grass-lands that the injurious practice of burning is still carried on, especially in southern districts where farming is more extensively carried on than in the northern and less inhabited districts. The practice alluded to prevails to a larger degree than elsewhere in woods growing on a soil of a granite or Tertiary formations. However as it has been strictly forbidden by law, this injurious custom may entirely disappear in the near future.

Mushroons.-Mushrooms are the most valuable minor forest produce in Japan, there being over ten principal edible fungii growing to a greater or less extent throughout the country. Of these the Shiitake is the most important, and constitutes one of the staple export items, its export to China, Hawaii, Hongkong, India, etc., having reached to 860,671 yen in value in 1901 . The mushroom is produced in larger quantities than elsewhere in Hyūga, Bungo, Kii. Ise, etc., where such species of wood as Kunugi, Konara, Soro, Shide, etc., which the mushroom prefers to grow on in preference to other trees abounding in the forests. Sometimes forests are prepared in those districts with the main object of producing the mushroom, and indeed this practice is often found more profitable than the ordinary wood-growing industry. In a forest intended for the growth of mushrooms a system of rotation of from 18 to 25 years is carried on and the forest is therefore managed according to the coppice system. The mushroom, moreover, possesses this special ardvantage, of growing both in spring and autumn, and naturally there are two varieties, one being more fragrant than the other. "f

Matsutake (Armilaria edulis Berk) grows in forests of Akamatsu, wpecially those growing on soil of the Tertiary and granite formations found in the southem districts. What is interesting about this edible fungus is that it grows most when a pine forest has be come worn out by excessive utilization of its produce. Consequently with the improver forest manargement that was recently introduced, the output of the fungus has shown a tendency to diminish. This fungus is perhaps more popular than the preceding variety as a culinary dainty. The only defect about it is its delicate texture, and the consequent difficulty of keeping it dry, as can be done satisfactorily with the "Shii" mushroom. Consequently the season of" 
the "Pine-mushroom" last only about a month in the autumn. The business of timning the fungus has lately been started, and as the tinned samples are reported to have been favorably received in foreign markets, this mushroom may by proper treatment becorne a valuable export item like the other variety. It may be added that in the State forests in charge of the Ōsaka and Okayama Major Forest Offices the greater portion of the forest revenues is at present derived from the sale of "Pine-mushrooms" growing in them.

Seeds, Acorns, Exc.-Seers eonstitute another important minor forest produce. They are collected for various purpnses. The seeds of trees of the Rhus species are principally used for making woodwax, which is very much in demand both at home and abroad. In 1901 the export reached 610,000 yen worth approximately. It was formerly used for making candles, but at present it is also used for giving lustre to woven goods, lubricating metallic ware to prevent rust, while in Europe it serves the purpose of sealingwax. The trees are grown in the premises of shrines and temples, in public forests owned by private individuals. They grow best in sumny slopes.

The business of collecting seeds to produce seedlings is also a profitable piece of minor work, especially since the work of treeplanting both by the Government and private people has become active. There are at present not a small number of merchants dealing in this special line of seeds. The seeds that are in larger demand than others are those of Sugi, followed by those of Alomatsu, Hinoki, Kunugi and Kaiamatsu. The seeds of the Sugi and Hinoki are produced most at Yoshino, in Yamato, and Muro, in Kii, where a machine of improved style is used for drying the seeds. The seeds of Kunugi come from Ikeda, in Settsu, and Nasu, in Shimotsuke, those of Karamatsu from Saku district, Shinano, and the seeds of Aka-matsu from many places in Kyūshu, Shikoku, and other warm districts.

Further, some acorns and nuts are useful for procuring oils, the seeds collected for the purpose being those of the heech, camelia, Shikimi, Aburrogiri, Inu-gaya, walnut, etc. The demand for those oils having been extensive lately owing to great development in the use of machinery, these seed-eollectors can often 
earn as much as threefold of the daily wages derived from other kinds of work.

BARKS.-The barks of oak trees are valuable for dyeing and tanning, and the oak forests in northern Honshu and Hokkaido produce an abundance of these barks. All those forests are the result of natural growth and have not been artificially stocked with the object of producing the barks. The barks of alders, chestnuts, Tsuga, Nara, etc. are also used for tanning and dyeing.

STONEs.-Except in forests where the removal of stones is inadmissible for important reasons, the utilization of forest-stones is extensively carried on, the demand for stones for various public works having become unusually great recently. Of these stones, granites and andesites are most valuable among igneous rocks. The former come most from the districts bordering on the Inland Sea and the islands situated in it, as also from Mino, Owari, and Mount Tsukuba. Tufa-rocks found in Hakone and Izu, slate-stones in Rikuzen and Kōluke, calcareous stones in Mino are also valuable for building and other purposes. Marbie-stones are produced at Kuji district of Hitachi. Then granites supply materials to the potters of Seto and Owari, while the earths used by the potters of Karatsu and Hizen are liparite. It may be stated that the extraordinary demand for stones that has spring up of late has raised the market price to about double what it was formerly.

On the whole the revenue from minor produce is comparatively small in State forests, as may be seen from these figures: $1892,119,912$ yen; $1895,73,575$ yen; 1898, 117,268 yen; $1901,158,665$ yen. The revenue from mushrooms, barks, seeds and acorns, and stones promises to grow larger, but that from other produce is dwindling chiefly orwing to the larger extent of free utilization allowed to the people.

IXDUSTRIAL Uses of WOOD.-Though the industrial uses of woor are quite active in our country, the industry as a business is limited in many cases in scope.

Capionisatron.- This is most important among the industrial uses of wood, work being carried on wherever a broad-leafed forest available for the purpose exists. The Bicho charcoal industry in Kumano, Kii, is most famous in this line throughout the country. The carbonisation industry has perceptibly been affected by the 
greater use of coal than before as a substitute of charcoal, but as our customs prevent us from dispensing with a large consumption of charcoal, the industry will remain an important one.

Recently the work of procuring vinegar as by-product of carbonisation was started in several places, especially in the southern districts. Eight such workshops were on operation according to the latest inquires. Other chemical substances besides vinegar are produced at the shops.

The establishment of saw-mills of an improved style is another sign of the development of forest industries, as a recent large demand for sawn-timbers necessitates a certain unity of dimensions and a mode of conversion most convenient for transport. According to the latest available returns there were 14 saw-mills worked by steam, with an aggregate horse-powers of 317 , and six saw-mills worked by water power with an aggregate horse power of 52.

MATCH-STICKS, - Though the industry is one of recent origin it forms one of the most important itmes of export of our wood industries, there being, according to the latest available returns, 85 workshops employing 3,552 hands. The export reached about 7,400,000 yen in 1901. The industry is most active in Hokkaidō, where the timbers from which the sticks are made abound, these being species of aspen and poplars.

The Pulp. - This business is of more recent origin than the preceeding industry, but it now occupies almost an equally important place. The pulp consumed in Japan formerly came from abroad, but the steady development of the paper industry having given a powerful incentive to the pulp-making business, Japan now possesses, according to the latest available returns, five mills worked by steam power. Shirobe, Momi, Toga, Todo-matsu, Yezo-matsu, etc. are generally requisitioned to supply the raw material. These species are at present found abundantly in Japan.

Other branches of the wood industry are camphor-making, bamboo-ware making, wheelwright, joiner's, turner's, cooper's work, stc. may be mentioned.

Generally speaking the forest industry is destined to show a far greater activity and developrent in Japan. 


\section{Y. FOREST PLANTING AND TRANSPORT.}

Planting. - The effect of reckless felling soon after the Restoration is glaringly shown to-day in the granite hills of Ômi, Mino and in the districts bordering on the Inland Sea.

In order to check this wasteful system of felling, in 1875 the Government issued regulations for investigating the condition of State forests, with the special object of ascertaining the extent of the forests that had been felled, while in the following year an experimental forest-planting ground was established at Nishigahara, Oji. Again, in the next year, arrangements were made for encouraging the planting of State forests by private individuals by offering them a certain percentage of the profit arising from the produce of the forests planted in this way. The system has not proved quite as satisfactorily as was expected at first, though the areas planted under these conditions have reached about 80,000 cho.

Encourafing Plan'ing.-Prior to the carrying into effect of the Civic Corporation System sylvicultural works other than those car. ried on by the Government were few and far between, and it was only in forests belonging to private individuals in Yoshino and Muro that planting was carried on in anything like a systematic manner. Subsequent to the promulgation of that self goverument organization in which provision about communal funds were made, the idea hegan gradually to prevail that forest-planting was the best plan for augumenting these funds. The idea gained special force owing to the encouragement and the grant-in-aids extended by the local authorities in accordance with the provisions of the Forest Law subsequently enforced. The result was that during the two years of 1898 and 1899 no less than 426,595 cho of communal areas were planted, the number of seedlings and young trees planted totalling $801,022,357$. The work generally received more or less assistance from the local authorities, that assistance generally taking the form of technica! advise.

Planting in State ani) Imperial ionsers. - Cheanwhile the work of planting went on steadily in the State forests. At first it mainly consisted of regenerating the cleared areas, and therefore not 
much attention could be devoted to the deforested areas. In $\mathbf{1 8 9 5}$ the investigation relating to open spaces was completed, and a working plan according to the high forest system was drawn up. From 1899 when the second State forest adjustment programme had been completed, the arrangement of open spaces could be made more satisfactorily than before. Between 1898 and 1898, $43,149.9$ cho of State forest areas received planting, while during the three years ending 1901 the areas similarly treated reached 34,897 cho. In the former total 80 per cent. consisted of the work of regenerating cleared areas, and only 30 of planting waste spaces, while in the latter the open space work comprised 55 per cent., the remaining 45 consisting of regeneration work.

The extent of bare land being comparatively small in forests belonging to the Imperial Household, planting is carried out mostly for regenerating cleared areas, the planted areas of this descriptioil amounting to $12,510.4$ cho during the ten years ending 1901 .

Metrods of Plantring.-The system followed in planting operations must of course be different according to the locality and other causes, always keeping in view the main object of producing a perfect forest formation capable of returning a regular revenue.

The plans pursued in pursuance of that maid object are these :-

1. Natural regeneration.

2. Sowing.

3. Planting of young plants.

4. Planting in dunes and patches of shifting sand.

The first method was almost universally adopted in former times, but this is no longer popular in these days when the knowledge of forest management possessed by foresters has come highly developed, for if that method is the easiest and the least troublesome, nontheless it is not advisable in view of the necessity of effecting a thorough improrement in our sylvicultural conditions. However on steep slopes and in protection forests demanding special treatment this method is still used to extent.

Generally sowing is made to supplement the necessarily fickle operation of the method of natural regeneration. In cases when sowing is carried on by itself it is done by ridge-sowing, broad-cast- 
sowing, line-sowing, etc. Oaks, beeches, $A k \alpha$-matsu, etc can be grown satisfactorily by sowing.

However, the planting of young trees is the commonest method in artificial regeneration, this method being adopted in the greater number of cases in State forests and in forests belonging to the Imperial Household. Generally seedlings are transplanted to the woods after they have grown two or three years in the nursery, the tree of planting per cho ranging between 4,500 to 6,000 young trees. As it is hardly possible to expect all of them to grow vigorously in the new soil, about 20 or 30 per cent. of the planted young trees must be supplemented in year or two after the transplanting.

The method of planting by means of cuttings is practically identical in operation and result with the method described above, only that this method cannot be adopted for all species of trees. In Higo and Hyuga the regeneration of Benko Sugi has been exclusively carried out by this method, while it is similarly applied to Doro, Hakoyanagi, etc. growing in Hokkaidō, Hiba in Aomori and Noto.

In dunes and in plains of shifting sand, works to prevent earth from slipping away should first be constructed, these works generally consisting in straw-work or bramble-work or sometimes in sods. The trees selected for this particular method of planting are generally Kuromatsu and Bageshibari, mixed at the rate of 3 of the former to 2 of the latter. Planting should be done at the rate of 14,000 to 18,000 per cho. Travellers travelling from Shimonoseki to Kobe by the Sanyo Railroad must notice in Bizen and Harima many hills of reddish soil covered with young pine trees planted in terraces. Similar pine-clad terraces are seen along the Tōkaidō route. All those plantations have been made by this particular mode of planting.

Extrext of Planted Areas. - The extent and nature of the planting operations carried on in the State forests and in the forests belonging to the Imperial Household during the ten years ending 19() 1 may be demonstrated by the following figures :- 
STATE FORESTS.

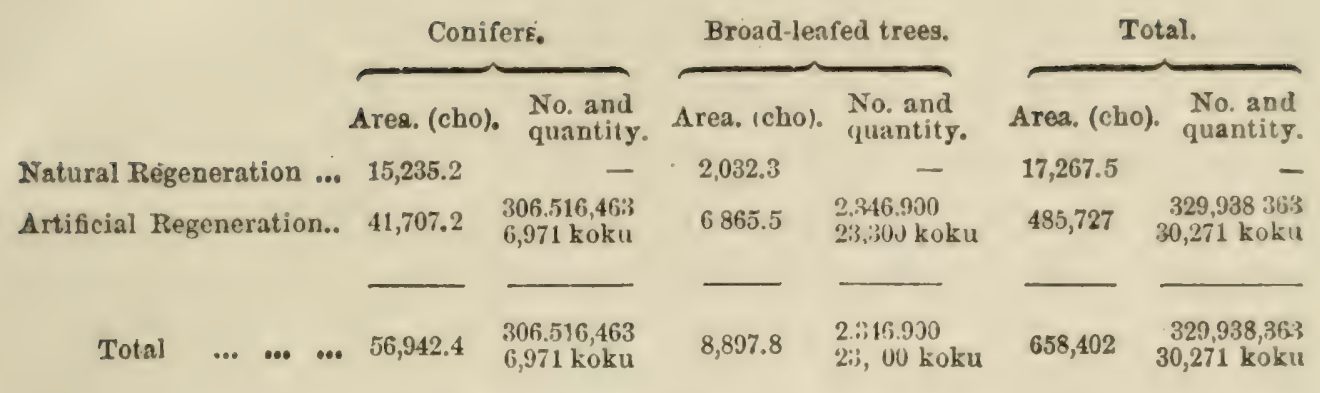

IMPERIAL HOUSEHOLD FORESTS.

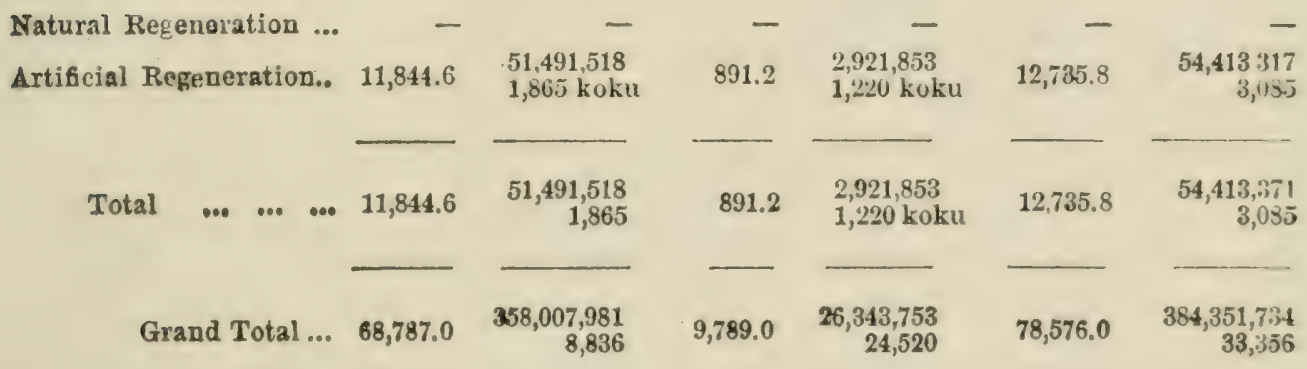

Kind of Planted trees.-As may be seen from the foregoing table, the areas planted with conifers are about nine-fold those planted with broad-leafed trees, and this predominance of conifers over trees of the other description will form a characteristic feature of our future sylvicultural system. The reason why conifers are as much preferred to the other kind of trees is because that with the present activity in the work of house building and in the carrying on of public works the timbers of the conifers are more in demand than that of broad-leafed trees, so that at present except in retired districts most of the sylvicultural undertakings are carried out with the object of producing timbers of conifers.

As to the relative ratio of the different species planted, Singi occupied about 48.3 per cent. of the entire area, pines 25.6 per cent., Hinoki 8.8 per cent., Keyaki 3.6 per cent., the remaining 9.7 per cent. being planted by two or three different species. Again, in the relative ratio of conifers, Sugi, Aka-matsu, and Hinoki predominated over the others, while in broad-leafed trees Keyaki, camphortrees, Kunugi, etc. surpassed the others.

This overwheling predominance of conifers is a point which 
ought to demand the serious consideration of all those interested in our forest policy. There is another fact that similarly demands their attention and that is the growing tendency to prepare pure forests instead of mixed forests. In fact, of the forests thus far stocked no less than 98 per cent. are of pure forests, only 2 per cent. being mixed forests. This remark applies both to conifers and broad-leafed trees. But it should be remembered that a pure forest is liable to give rise to various evils, besides being attended by difficulties in management. Indeed this point has lately begun to be perceived by foresters and others concerned, who acknowledge the advantage of mixing more or less light-demanding species with conifers. At least this is the policy now pursued in State forests, where the planing of broad-leafed trees is attended to so long as circumstances permit.

NURSERY-BEDs.-The efficacy of tive work of forest-planting depending essentially on the soundness of the seeds and seedlings and also on the skill of the employed labor the utmost care is exercised in those respects. In the State forests and Imperial Household forests the seeds or seedlings to be used are only those that are collected or grown on the spot. The nursery-beds attached to those forests numbered 407 at the end of 1900 , with an aggregate area of 622.1 cho for State forests and 111 with an area of 101.9 cho for other forests. Then in order to procure as cheaply as possible the labor required in tending the nurseries, and also to facilitate the work of transplanting, these beds are located in places combining as much as possible these two conveniences. They are laid out in as many places as possible.

The seedlings grown in nursery-beds are generally transplanted after full three years' growth in the beds, and when they have attained the height of 1 th to 2 shaku. Some species, Sugi for instance, admit of being transplanted after two years' growth, while some broad-leafer species, such as Hiba, Koyamaki, etc. require tive or seven years' nursery growth. Of course in places where the injury from game is apprehended even Sugi must be left to stand five or six years in the beds. The quantity of seeds sown and the number of seedlings grown in State forests nurseries during the ten years ended 1901 are given in the following table:- 


\begin{tabular}{|c|c|c|c|c|c|c|c|}
\hline \multirow{2}{*}{ Year. } & & & & \multicolumn{2}{|c|}{ Conifers. } & \multicolumn{2}{|c|}{ Broad-Leafed trees. } \\
\hline & & & & $\begin{array}{l}\text { Quantity of } \\
\text { Seeds. Koku. }\end{array}$ & $\begin{array}{c}\text { No. of } \\
\text { Seedlings. }\end{array}$ & $\begin{array}{l}\text { Quantity of } \\
\text { Seeds. Koku. }\end{array}$ & $\begin{array}{l}\text { No, of } \\
\text { - Seedlings. }\end{array}$ \\
\hline 1892 & $\cdots$ & $\cdots$ & $\cdots\{$ & $\begin{array}{l}18,083 \text { koku. } \\
15,000 \mathrm{No} \text {. }\end{array}$ & $5,158,354$ No. & 18,331 & 940,109 \\
\hline 1893 & $\cdots$ & $\cdots$ & $\cdots\{$ & $\begin{array}{r}16,009 \\
523,400\end{array}$ & $4,963,780$ & 31,267 & 765,851 \\
\hline 1894 & $\cdots$ & $\cdots$ & $\cdots$ & $\begin{array}{r}24,793 \\
544,000\end{array}$ & $7 \cdot 196,173$ & 52,882 & 780,746 \\
\hline I895 & $\cdots$ & ... & & $\begin{array}{r}21,805 \\
501,400\end{array}$ & $7,560,593$ & 52,681 & I,61 1,997 \\
\hline 1896 & $\cdots$ & $\cdots$ & .. & $\begin{array}{r}\mathbf{1} 8, \mathbf{1} 90 \\
732,880\end{array}$ & II $, 758,563$ & 65,990 & $\mathbf{I}, 847,554$ \\
\hline I897 & $\cdots$ & $\cdots$ & $\cdots$ & 23,799 & $12,006,878$ & 32,835 & I,or3,359 \\
\hline 1898 & $\cdots$ & $\cdots$ & & $\begin{array}{r}28,748 \\
324,716\end{array}$ & I $3,377,054$ & 48,114 & $\mathrm{x}, 298,175$ \\
\hline 1899 & $\cdots$ & $\cdots$ & $\cdots$ & 78,021 & $14,359,413$ & 140,528 & 634,667 \\
\hline 1900 & $\cdots$ & $\cdots$ & $\cdots$ & 107,554 & 20,896, I 29 & 313,750 & $\mathbf{I}, \mathbf{1} 28, \mathbf{1} 82$ \\
\hline I90I & $\cdots$ & $\cdots$ & & $\begin{array}{r}145,811 \\
70,000 \\
\end{array}$ & $29,768,092$ & 398,189 & $2,469,590$ \\
\hline & otal & $\cdots$ & & $\begin{array}{r}482,813 \\
2,846,396\end{array}$ & I 27,045,029 & $1,154,527$ & I 2,490,230 \\
\hline
\end{tabular}

The sudden activity of the nursery work from 1899 was due to the fact that in that year a special account system was allowed in forestry management. Then the rate of conifers and broad-leafed trees in the seedlings raised amounted to 10 of the former to 1 of the latter. In the conifers, Sugi, Hinoki, Kara-matsu, Alia-matsu. predominated over others.

Treatmext of Planted-Areas.-In newly-planted areas, except in areas of protection planting, the cutting of grass is generally made every year for the space of three years subsequent to the planting. Then during the next ten years the grass-cutting is done every other year. Thinnirg is carried out for tending the growth of young trees and for preserving the forest-aspect. During the five years ended 1901, 13,588.3 cho of State forests were subjected to this thimning process, by which 229,146 cubic shatu of wood for industrial uses was obtained, besides, 156,019 stacks of firwood, and 192,630 bundles of branch-litters. These intermediate forest produce are growing more and more valuable owing to the greater demands on them for various purposes.

Arboricultural experinents,-Arboricultural experiments 
were first started at Nishigahara in 1876 , but it was not until after 1897 that the work became really brisk. In that year eight experimental nurseries were established in different typical places, and, under the supervision of the chiefs of the nearest Major Forestry Offices, they were made to carry out investigations relative to sylvicultural climate, selection of species best calculated to improve the forestry aspect, germination and growth of young plants, and such subjects. The overseers of the nurseries were made to submit to the Minister of Agriculture and Commerce reports on the results on the investigations. At the same time the central nursery established at Kami Meguro, suburb of Tokyo, under the direct control of the Forestry Bureau, was made to examine the reports sent in from the local offices.

Exotic TREes.-The experiments on the exotic species being still incomplete, it is not possible to give any authoritative statement as to the relative adaptability to Japanese soil of the various species planted in the nurseries. Judging from the aspect of growth, the following species are likely to prove a valuable addition to Japanese sylviculture.

Robinia Pseudoacacia, L. (Imported from the U. S. A.). Sown in the nursery in 1900, the plants have already grown to the height of over 4 metres. The principal merits of this species are quick growth, adaptability even to poor soil, and the presence of strong reproductive power, shoots springing up from the side-roots. As a substitute for the indigenous Hage-shibari the tree may serve even better than that shrub for the purpose of preventing the drifting of sand and landslip. The wood is also hard and well suited for earthworks.

Pinus rigida (Imported from the U.S.A.). Sown in 1900, the plants have grown over 1 metre high. In respect to strong reproductive power, hardy character, and adaptability even to poor soil, this species resembles our $A k a-m a t s u$ very much, and like it the species is apparenty suited for dunes and shifting sands.

Populus monilifera (Imported from the T.S.A.). The young plants ineasuriug 0.7 metre in height were imported from that, country in 1899 and transplanted to the nursery. They have 
attained the height of over 4 metres. Both in growth and reproductive power they are very strong, being capable of artificial regeneration by cuttings. As material for match-wood, the tree is as excellent as the indigenous popular.

Juniperus Virginiana (Imported from the U.S.A.). Those sown in 1890 have attained the height of $1 \frac{1}{2}$ metres, and those in 1900 that of 1 metre. Judging from the experiments thus far carried out, it does not seem difficult to acclamatise the species to Japanese soil. In that case the rood will lead to encouraging our lead-pencil industry, which has firiled to attain any marked development for lack of suitable wood.

Of the other exotic species experimentally planted in the nurseries, the German Alnus glutinosa, the American Pinus species," the Himalayan Cedrus Devdara, and some other. species are likely to prove valuable trees for planting in exposed places. The Himalayan Cedrus Devdara also makes a fine garden ornament.

Forest-roads AND RIVER-Transport work. - Before the Restoration, owing rather to the excessive care exercised by feudal princes for the preservation of their forests and the enforcement of what we may call the "closed door" policy of administration in their duminions, there were grave obstacles to the efficient management of forests and their exploitation. Endeavors have been made for obviating those obstacles, and in such of those State or Imperial Household forests that are of a permanent nature or that admit of financial treatment, the work of constructing forest roads has been carried out so far as circumstances permitted.

Fonest roads - According to the existing rules forest-roads are divided into two kinds, main roads and subsidiary roads. Further, they are divider into railed-roads, cart-tracks, roads made of wood, footpaths and cattle-paths. The first three are considered as main-roals and the latter two as subsidiary roads. A main-road must be connectad with a railroad or with a highway, while a subsidiary-roal must be connected with a main-road. A highway, though intenife] for general traffic, often receives from the Department of Agric.nture and Commerce some help towards its extension and repair, pro vided such highway is judged to facilitate the trausport of timber. 
Owing to the inconvenience of procuring labor and materials for construction, the cost of constructing forest-roads is generally high, the average per $r i$ of main-road amounting to over 6,500 yen and that of subsidiary-road to about 4,000 yen. The cost of bridge-making is equally high, as a bridge in a forest-road is to be constructed over a rapid steam liable to overflow. This question of expenses very much therefore ubstructs the progress of the construction of forest-roads, so that during the ten years beginning in 1892 the roads constructed in State forests have not exceeded 776,677 metres in length, of which the following were constructed from 1898 to 1901 :-

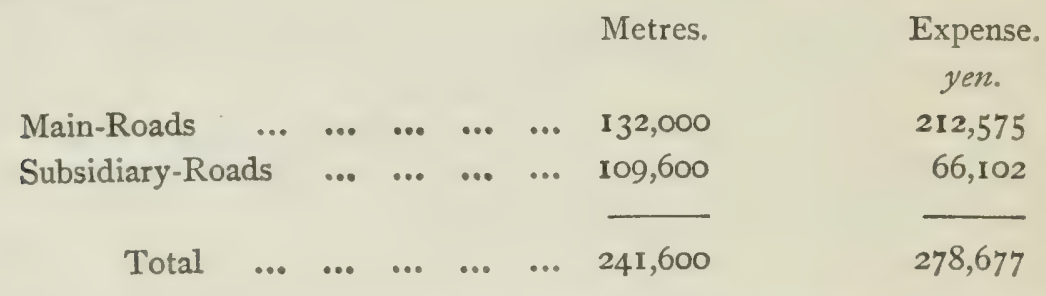

The roads recently constructed in the Imperial forest areas follows :Metres.

Expense. yen.

$\begin{array}{rrrrrrrrr}\text { Main-Roads } & \ldots & \ldots & \ldots & \ldots & \ldots & 44,140 & & 55,833 \\ \text { Subsidiary-Roads } & \ldots & \ldots & \ldots & \ldots & 28,080 & & 26,708 \\ & & & & & & - & \\ \text { Total } & \ldots & \ldots & \ldots & \ldots & \ldots & 72,220 & & 82,541\end{array}$

Besides the above, the tracks laid with 12 pound-rails in the Imperial forests at Kiso measure 8,212 metres, the expense required being 14,680 yen.

In the colder districts, such as Hokkaido or the north-eastern part of Honshu, the wood is largely carried over liardened suow in winter at a very small expense.

River Transport of Tmbers.-The transport of timber by rivers has been carried on extensively from former days, the conveyance of Kiso wood on the river Kiso, of Nagakizawa wood on the river Noshiro, and of Kitayama wood on the Shingu heing some of the important cases of the regular river-transport of timber. However, in orrler to make rivers serve still more efficiently this purpose, all the obstacles in their course should be removed, the river-banks should 
be made strengthened, while in the lower course where a wood-depot is to be formed damming-work should be constructed. From $1899 \mathrm{t}$, 1901 the obstacles were removed over 32,800 metres of river-beris and the stones thus taken out of the bottom covered 49,176 cubic tsulw.

\section{WOOD PRODUCE.}

General Remarks.-Data on forestry yield being unavailable in the case of privately-owned forests, we must content ourselves in this section with giving the data in comnection with the State forests measuring about $7,500,000$ cho and the Imperial forests measuring about 2 millions.

It is hardly necessary to state that the yield from the forests varies considerably according to position and lucal conditions, and that while the harvest of convertible timber depends upon the species of the trees and their growth, the amount of the financial yield depends upon the locale of the growing stock, the relative facilities of transport, and the demands on the market.

Harvest of Convertible Timbers.-The harvest of State forests continues to increase with the progress of the work of management, and, compared with what it was 10 years ago, the yield at present shows an increase of about 35 per cent. as stated in the following table :-

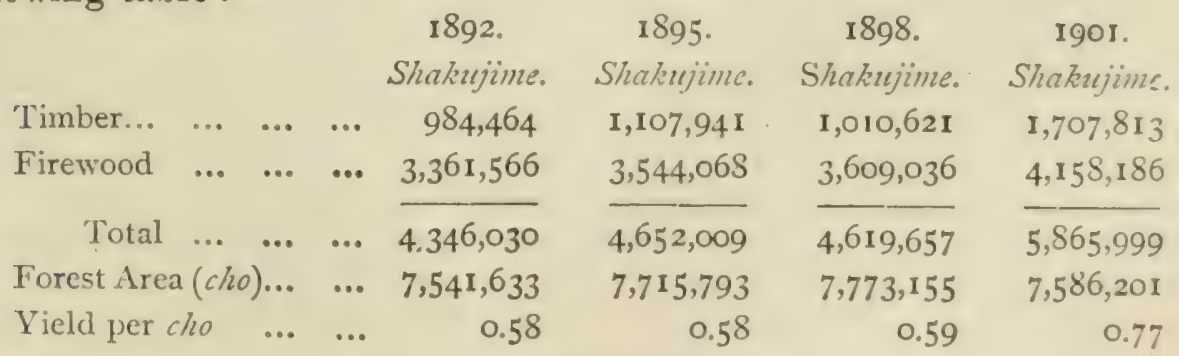

Note:-In the foregoing figures the harvest of root, stump-wood, and faggots is excluded, while fractions of a shakujimi are also omitted. A shakujime measures 12 cubic shaku and corresponds to about a third of I cubic metre. This remark applies to all the subsequent tables of a similar description.

The increase of the harvest has been brought about by a longer thining made possible by the improved method of management and by the extension of the utilization area which was in tum dite to 
development of means of transportation. Indeed the utilization area of State forests increased from about 18 per cent. in 1892 of the whole area to about 21 per cent. in 1901. In other words, the rate of utilization area increased during the period in question by 17 per cent. as against 35 per cent. of the volume of the timberharvest.

The harrest, according to the foregoing table, increased during the specified period from 0.58 shakizime per cho to 0.78 ; and these compared with the respective utilization areas correspond to 3.2 to 3.7

The volume of the harvest as compared with the volume of the growing-stock in the State forests is extremely small, and indeed does not reach even one half of what it should be. The reason of this abnormal yield must be sought in the fact that in most of the forests situated in hilly districts the presence of miscellaneous trees is seriously affecting the growth of timber-trees, while in most of the forests the growing-stock has not yet attained the normal "ageclasses." Further, the Government is disposed to minimize, till the management programme is completed. the volume of the yearly fellings, while the imperfect means of transport, absolutely considered, very much affect the extent of the utilization area.

FinANCIAL YIELD.-The State-forests, hampered as they are from various inconvenient conditions, are placed in a highly disadvantageous situation, so far as the financial side of yeild is concerned. This point is significantly shown in the following figures showing the yield during the 10 years ending 1901 :-

\begin{tabular}{|c|c|c|c|c|c|c|c|}
\hline Timbers & $\ldots$ & $\ldots$ & $\ldots$ & $\begin{array}{c}1892 . \\
y<1 . \\
342,556\end{array}$ & $\begin{array}{c}1895 . \\
\text { yen. } \\
555,906\end{array}$ & $\begin{array}{c}1898 . \\
y^{\prime} e n . \\
767,842\end{array}$ & $\begin{array}{c}\mathbf{1} 90 \mathbf{1} \\
\text { yen. } \\
\mathbf{I}, 369, \mathbf{I} 7 \mathbf{I}\end{array}$ \\
\hline Firewood & $\ldots$ & $\ldots$ & $\ldots$ & 213,709 & 299,449 & 372,515 & $486,14 I$ \\
\hline $\begin{array}{c}\text { Root, } S \\
\text { Fagots, }\end{array}$ & $\begin{array}{l}\text { tump } \\
\text { etc. }\end{array}$ & $\begin{array}{l}-w o \\
\ldots\end{array}$ & $\left.\begin{array}{c}\text { od, } \\
\ldots\end{array}\right\}$ & 66,324 & 19,348 & 28,708 & 37,880 \\
\hline Minor Pro & duce & $\ldots$ & $\cdots$ & 120,229 & 73,755 & $I_{42,904}$ & 158,655 \\
\hline Rent ... & $\ldots$ & ... & $\ldots$ & 23,618 & $25,36 \mathbf{I}$ & 46,323 & 73,689 \\
\hline Sundries & $\cdots$ & ... & $\cdots$ & 44,623 & 24,801 & 93,374 & 50,986 \\
\hline Total & $\ldots$ & $\ldots$ & ... & 811,059 & 998,620 & $1,451,666$ & $2,176,522$ \\
\hline Total Are & a (cho & p)... & $\ldots$ & $7,541,633$ & $7,715,793$ & $7,773,155$ & $7,581,201$ \\
\hline Yield per & cho & $\ldots$ & $\ldots$ & 0.108 & 0.129 & 0.187 & 0.288 \\
\hline
\end{tabular}

Fote:-In the above table, fractions of a yen are omilted, cxecpt in the figures representing the yield per cho. 
Though absonately considered, the yield of only 0.288 yen per cho is exceedingly small, still it must be regarded with satisfaction on account of the relative progress that it indicates. "The record for 1892 as compared with that of 1895 shows an inclease of 19 per cent., advanced to 73 per cent. in the next three years, and to 260 per cent. in the subequent three years. Again, when compared with the utilization area only, instear of the whole area, the yield per cho increased during the ten years from 0.647 yen to 1.386 yen.

This creditable progress, relatively speaking, has been brought about not merely by an increase in the volume of the harvest, but principally by the recent growing demand for timber with the consecuent rise of the market price, and by the diminution of transport expenses owing to the greater facilities offered by the improved means of communication. Above all the receipt from timbers has been strikingly increased, these timbers being mostly the timber of conifers such as Sugi, Hinoki, Hiba, Momi, Alamatsu, etc. Poles produced by thining were till ten years ago practically destitute of value but these now command a good price on the market. The rapidity with which the yield from timbers has adranced during the ten years under review is indeed remarkable, for while it has been quadrupled during that period the yield from firewood has only been doubled.

Expexpiture. - With the increase in the gross yield, the expenditures have necessarily been expanded. In 1892 the expenditure stood at 522,762 yen, but during the subsequent ten years the amount has been almost doubled and has risen to 1,029,966 yen. This increase, though partly due to the rise of wages and of the price of commodities, a phenomeno. 1 inseparable from the progress of the time, was more attributable to the expanded scope of improvement measures :-

\begin{tabular}{|c|c|c|c|c|c|c|c|}
\hline \multirow[t]{2}{*}{ Year. } & & & Area. & $\begin{array}{c}\text { Management } \\
\text { Expense. }\end{array}$ & $\begin{array}{l}\text { Working } \\
\text { Expense. }\end{array}$ & Total. & $\begin{array}{l}\text { Expense } \\
\text { per cho. }\end{array}$ \\
\hline & & & yen. & yen. & yen. & yen. & yen. \\
\hline $1892 \ldots$ & ... & ... & $7,541,633$ & 423,146 & 99,6 I6 & 522,762 & 0.070 \\
\hline $1895 \ldots$ & ... & ... & $7,715,793$ & 402,789 & 180,085 & $5^{82,874}$ & 0.076 \\
\hline 1898 ... & ... & ... & $7,773,155$ & 553,016 & 364,674 & 917,690 & 0.118 \\
\hline Igor hs & ... & ... & $7,581,201$ & 669,149 & 330,817 & $1,029,966$ & 0.137 \\
\hline
\end{tabular}


Note:-The management expense includes salaries of officials, office expenses, travelling expense, repair of offices, etc.; while the working expense comprise the cost of felling, transport, planting and all the other items incidental to the working of forests.

As stated in the foregoing table the average managing expense per cho increased during the ten years under review from 0.056 yen to 0.082 yen, while the average of the working expense increased from 0.013 yen to 0.044 yen. In other words, while the rate of increase of management expenses is about 60 per cent., that of working expenses is as much as 340 per cent. The ratio of management expense is rather high as compared with working expense, the former constituting, on an average, 68 and the latter 22, if we take the totil expense as 100 . This comparatively high rate of management expense is explained by the enormous extent of the State forests, and especially the fact that most of them require a thorough re-organization, and all these involve extraodinary trouble and expense. However, the ratio between management expense and working expense is gradually recovering normal proportion, for while in 1892 the management expense bore to the working expense the ratio of 21 to 5 , in 1901 the proportion became 21 to 10 . The proportion is sure to become more satisfactory when the second forestry adjustment programme now being carried out shall have been completed.

Profit.-Forestry yield is obtained by deducting from the gross receipts the working expense, while the net profit consist of what remains after the management expense has been deducted from the remainder. Calculated in that way, the net profit of State-forests stands thus:-

Year. Total Area. Gross Receipts. Gross DisNet Profit. Profit per cho.

$\begin{array}{rllllrrrr}1892 & \ldots & \ldots & \ldots & 7,541,633 & 811,059 & 522,762 & 288,292 & 0.038 \\ 1895 & \ldots & \ldots & \ldots & 7,715,793 & 998,620 & 582,874 & 415,746 & 0.054 \\ 1898 & \ldots & \ldots & \ldots & 7,773,155 & 1,451,666 & 917,690 & 533,970 & 0.069 \\ 1901 & \ldots & \ldots & \ldots & 7,586,201 & 2,176,522 & 1,029,966 & 1,146,556 & 0.151\end{array}$

The net profit per cho, as stated in the foregroing table, has increased from 0.0938 to 0.151 compared with the utilization area. 
The rate per cho was 0.212 yen in 1892 and it advanced to 0.72 yen ten years after.

Data About the Imperial Forfsts.-As forests that were comparatively regular in aspect were selected as Imperial forests on the occasion of setting apart a part of State forests as property of Imperial estate, the forests belonging to this special class, besides being easy to manage, are rich in conifers and valuable timber-trees, so that the harvest is more satisfactory than that in State forests. The harvest during the ten years commencing in 1892 is stated below :-

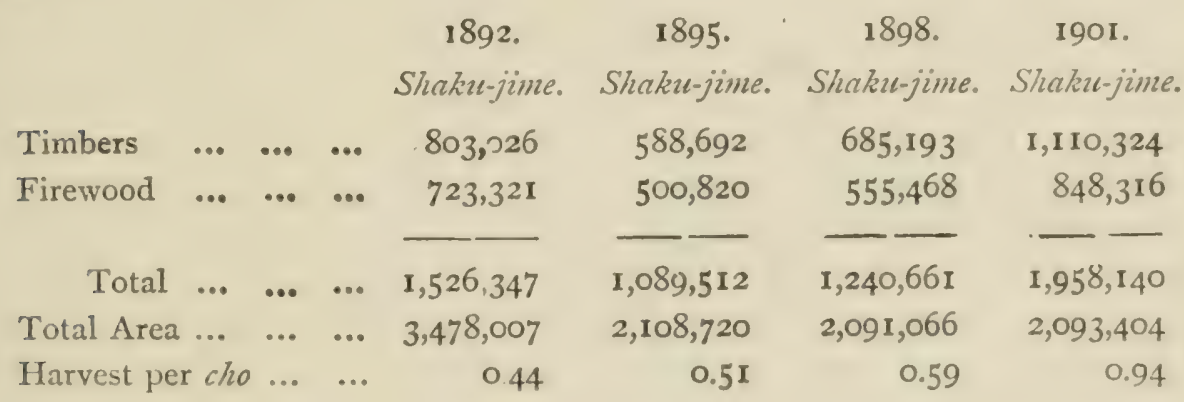

The average harvest per cho that was 0.44 in 1892 increased to 0.94 ten years after, an increase of more than two-fisll. The statistics on financial side are as follows:-

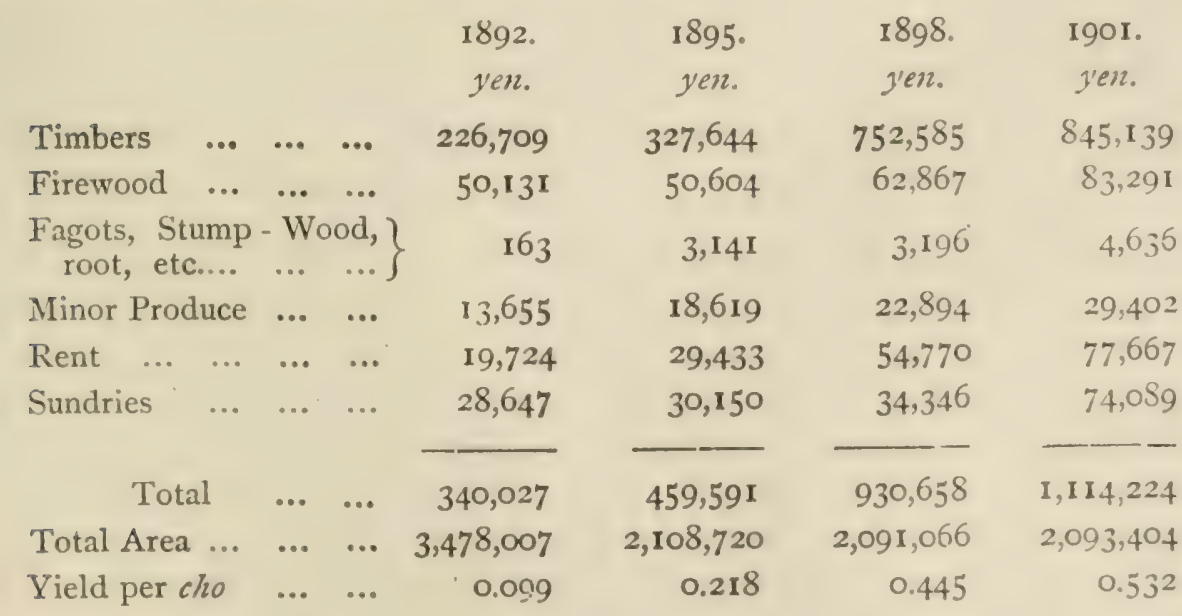

Just as in the case of the State forests, with the progress of the work of manarement along the economic line, the volume of the harvest and the amount of the gross receipts are gradully increasing, to make a still greater development as that work proceeds. Then the 
financial results of the administration of the Imperial forests are somewhat better, owing to the reasons mentioned above, than in the case of the State forests, for the gross receipts that stood at 0.095 yen per cho in 1892 advanced to 0.533 in 1901. As might naturally be expected, expense has also advanced.

\begin{tabular}{|c|c|c|c|c|c|}
\hline Total Area $($ cho $) \quad$.. $\quad \ldots$ & $\cdots$ & $\begin{array}{c}1892 . \\
3,478,007\end{array}$ & $\begin{array}{c}1895 \\
2,108,720\end{array}$ & $\begin{array}{c}1898 . \\
2,091,066\end{array}$ & $\begin{array}{c}1901 \\
2,093,404\end{array}$ \\
\hline Management Expense (yen) & ... & 106, I 54 & I 10, 138 & I I 5,29 I & 147,734 \\
\hline Working Expense $\left(y^{\prime} e n\right) \ldots$ & ... & 208,157 & I95,594 & 369,954 & 496,686 \\
\hline Total $(y e n) \quad \ldots \quad \ldots$ & $\cdots$ & 314,311 & $305,73^{2}$ & 485,245 & 644,420 \\
\hline Expense per cho (y'en) ... & ... & 0.090 & 0.145 & 0.232 & 0.308 \\
\hline
\end{tabular}

In respect to the increase of expense, the. Imperial forests are very much like the State forests, for during the period under review the rate per cho increased from 0.09 yen to 0.308 yen.

However, in contrast to the corresponding state of affairs in State forests, the ratio between the management expense and the working expense is entirely reversed, the former constituting only 27 and the latier 73 , out of the total expenses of 100, This coml parative smallness of the management expense in the Imperiaforests is explained by the fact that the forests, owing to their convenient location, and on account of their being comparatively well-organized do not require any large amount of money to be -pent on them. Thus while State forests required in 1901 management expense amounting to 0.092 yen per cho the corresponding fircure in Imperial forests was only 0.071. On the other hand, the average working expense of State forests in the year mentioned was 0.045 yen per cho against 0.337 in case of the other forests. 'This remarkable difference between the two is ascribable to the fact that while in State forests the forests-produce to be sold is generally done so in the shape of standing-trees, in the Imperial forests whatever produce becomes disprasable is directly utilized by the Household itself which of course undertakes the work of conversion.

The net profit from the Imperial forests as calculated by deducting the gross dishursements from the gross receipts was minue 22,640 yon in 1892, the loss being at the rate of 0.007 yen per chos subsequently conditions were restored to their normal aspect, for in 
1895 net profit grew to 0.045 yen per cho, to $0.125 \mathrm{in} 1898$ and to 0.138 in 1901. In other words, during the last seven years out of the ten under review, net protit was increased by 0.093 yen per cho.

\section{OFFICIAL SUPERYISION OF THE FORESTS.}

Controlling Offices.-Considerable changes have taken place. as to the official repository of power in regard to managing and supervising forests since the feudal princes have surrendered their ficf:- to their sovereign liege in 1stis. The forests held by them have beconne converted into State property. Suffice it to state that it was in 1878 that the existing Forestry Bureau was created and that affair relating to State forests and to forests at large were for the firss time placed under the control of a special office and that somethine like a regular system hegan to be evolved. This tendency became more manifest with the transfer of the Bureau in 18.81 to the control of the Department of Acriculture and Commeres, a Department of State that was created in that year. Subsequently the forestry policy of the Govermment has gone on acquiring greater importance and consistency.

According to the existing system, the Minister of Agriculture and Commerce is the supreme supervisor of all matters relating to State forests and to forests at large, and, subject to his control, the Forestry Bureau takes charge of all matters relating to the administration and scientific treatment of forests. The staff of the Bureau comprises, besides its director, four forest commissioners and ten clerks, and these attend to the working and treatment of State forests and supervision of private forests.

The right of supervision of private forests is derived from the Forest Law promulgated in 1897. In accoriance with the provisions. therein set forth, the Goverument extends to utilization forests suitable economic treatment of a positive nature, while. on the other hand, the negative policy of prohibiting felling and similar rentrictive measures is extended to protection forests. In all these matters the respective local Governors are made to act as supervisors in the 
first instance, the right of issuing final directions resting with the Minister of Agriculture and Commerce.

The control of State forests is conducted in accordance with Imperial Ordinance No. 18 issued in 1886, by which a regular system of management was elaborated. By that system the management is conducted by sixteen Major Forest Offices and 325 Minor Forest Offices.

Forest OfFices And JuRISDictron.-The following table shows the location, extent of jurisdiction, etc. of the Major Forest Offices.

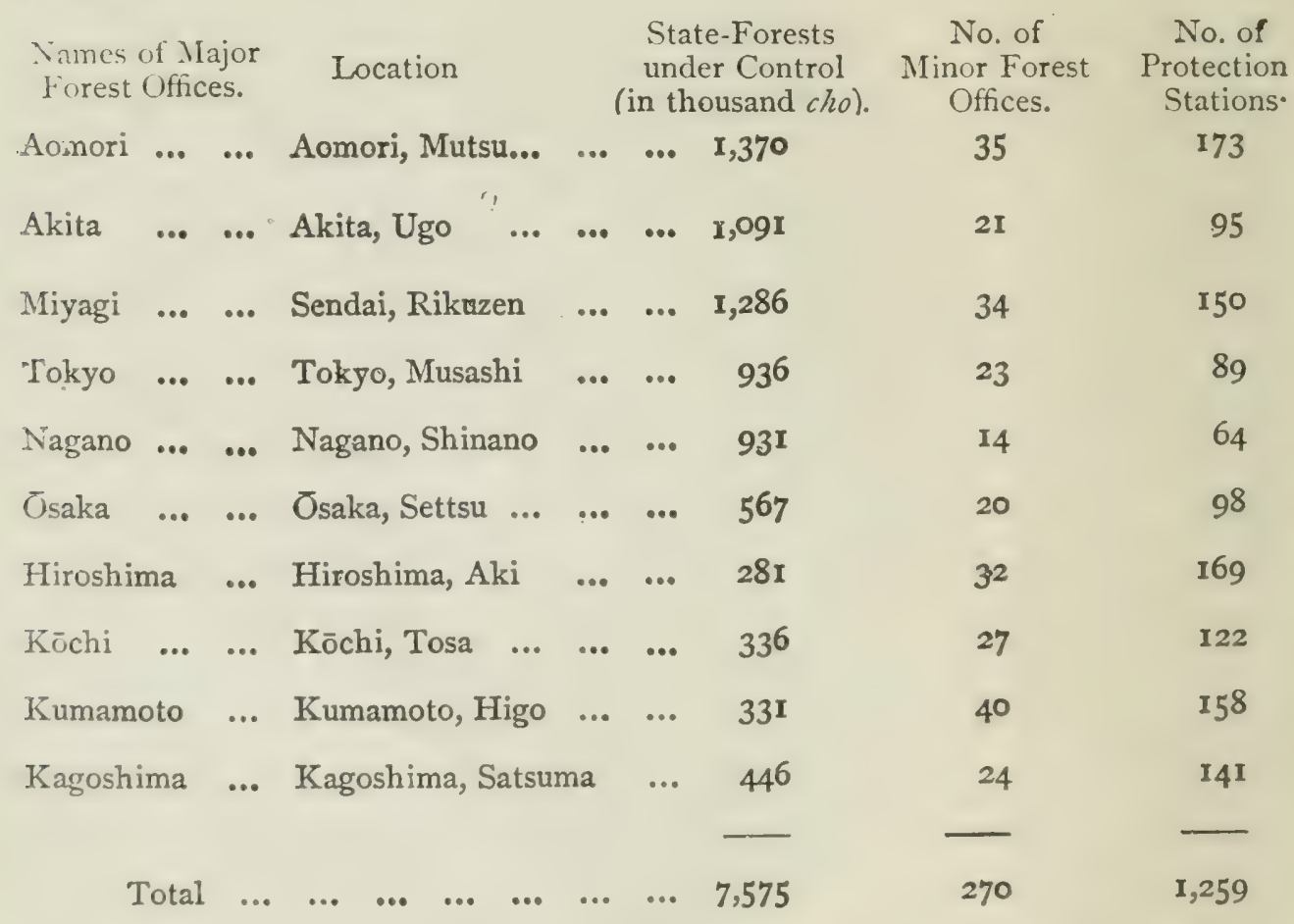

The foregoing table will show that the extent of the Major Firest Office's jurisdiction lies between the two extremes of $1,370,000$ tho of Aomori and 281,000 cho of Hiroshima, the average for the whole heing 757,500 approximately. A greater diversity is noticeable in the jurisdiction of Minor Forest Offices, this diversity heing unavoidahle in such a country as Japan where systematic forestry management is still in the inception stage and where means of communication are as yet imperfect, and the formation of forests is irregular. Thus while the Matsuyama Minor Office under the Kōchi Major Office, controls only 
2,000 cho, that of Liyama under the Nagano Major (Office, controls as much as 396,000 cho. The average for all the Minor Offices is 28,000 cho. It is natural that, with the progress of the work of economic management, the extent of jurisdiction of a Major and a Minor Forest Office will become more limited.

The number of protection stations also differs according to places. The average number to each Minor Office is three to eight, but in some exceptional cases as in that of the Tsunodate Minor Office which is subordinate to the Akita Major Office the number is as many as ten.

The foregoing organization applies to the State-forests under the control of the Department of Agriculture and Commerce but there are other kinds of State-forests in charge of other Departments of State.

The State forests in Hokkaido and Formosa are subject to the supervision of the Minister of Home Affairs.

The State forests in Okinawa, the seven islands of Izu, and Ogasawara, though belonging to the juriscliction of the Department of Agriculture and Commerce, are left for the convenience of the local administration, in charge of the respective local authorities who manage them subject to the supervision of the Minister of Agriculture and Commerce.

\section{YIII. FORESTRY EDUCATION.}

Collegrate Courses.- The remark that the progress of industry is a faithful reflection of the progress of exlucation is fittingly exemplified in the case of our forestry industry, for the recent striking development in our forestry economy must be regarded as an outcome of a similarly striking development in sylvicultural education.

It was in 1882 that the Tokyo Dendrological School, the first of its kind in Japan, was established at Nishigahara, but now at no less than 62 institutions the scienee and art of forestry is taught. Of that number three are imparting collegiate education, five a special course on forestry of secondary education grade, another five 
are giving a special course on the same subject of a somewhat lower grade, while the remaining 48 are imparting a general knowledge of forestry as a subsidiary subject to one or another of the main courses of practical education. It ought to be noted here that formerly all the important educational organs on forestry were subjoined to the Department of Agriculture and Commerce, but as it was judged more convenient to have them, transferred to the control of the Department of Education, this transfer was effected in 1890 .

The College of Agriculture of the Imperial University of Tokyo, the Sapporo Agricultural College, and the High Agricultural and Dendrological School at Iwate, are the three collegiate institutions in question.

In all of those collegiate courses, in compliance with the demand of the Government forestry authorities and of general foresters, special attention is paid to the training of specialists who are to combine adequate scientific and practical knowledge on forestry, and who, on leaving school, are qualified to attend with efficiency to the duty of managing and improving our forests. The Government is giving special encouragement to the study of this useful science, by offering to the graduates comparatively good posts.

The College of Agriculture is also provided with a briefer course on agriculture and dendrology.

Srimools of SE(onidary Grade.-The five schools of secondary education grade where a special course on dendrology is taught are as follows:-

Kiso Dendrological School $\quad \ldots \quad \ldots \quad \ldots \quad \ldots \quad$ Nishi Chikuma, Nagano-ken.

Aichi Agricultural and Dendrological School... Hekkai-gun, Aichi-ken.

Nara

" " " $"$

Shimane " " "

Arima

$\begin{array}{llll} & \Rightarrow & \ldots & \text { Yoshino-gun, Nara-ken. } \\ & " & \ldots & \text { Yatsuka-gun, Shimane-ken. } \\ & \quad & \ldots & \text { Arima-gun, Hyogo-ken. }\end{array}$

These schools are either public or communal institutions, and are under the direct control of their respective local Governors. The Inepartment of Education confines it: interference merely to 
matters regarding the unity of national practical education. Those schools receive a subsidy from the Treasury, the object of that subsidy being to encourage the cause of practical education. Then the students enjoy equal treatment as those at ondinary middle schools in respect. of conscription service, ordinary civil service, etc.

As these schools do not date back very far, they have not; yet turned out any graduates, but the number of students is steadily increasing, the attendance being 418 in all at present.

SCHOOLS OF LOWER GRADE. - The five schools of somewhat lower grade than the preceding ones are apprentice schools enjoying a grant-in-aid from the Treasury and are imparting an elementary knowledge of forestry to the students. The schools are maintained by communities which, from local circumstances, are interesteci in bringing up young men qualified to attend to forestry management: and to exploit the forest industry. The course of instruction extends for three years, and aceording to the latest available returns the students number 417 for all the schools.

Other Schools TEACHING Forestry. - Of the schools whose curriculum includes forestry 37 are of the secondary education crade, and 11 are of the higher primary education grade. Established long time back the list of graduates includes 1,323 for the former and 108 for the latter, while, at present the schools of higher grade have 4,364 attendants and the others 782 . As most of those schools teach agriculture, fishery or stockfarming besides giving instruction in forestry, the field of their service is very wide and their service may be easily available even in places where the cingrament of forest specialists is not possible.

Tranning Schools.-Lastly a short remark may be made about the Forestry Training School established at the Experimental Forestry Station at Meguro under the control of the Forestry Bureau of the Department of Agriculture and Commerce. The school is intend'ed to train men who are to attend to the management of State firrests and to engincering work, so that the course of stmly comprises forestry, geodesic and triangular surveying and topographical-drawing. It is the main idea of this institution to impart 
training of a thoroughly practical nature to as many students as possible within the shortest terms compatible with the demand of instruction.

\section{FORESTRY LEGISLATURE.}

The Forest Law already mentioned contains provisions about the control of utilization forests, protection forests, forest police, punitive rules, etc. A number of Imperial Ordinances for putting in operation the said law were promulgated at the same time, these Ordinances relating to the Local Forestry Council Rules, Conversion and Release of Protection Forests, Rules for putting the Forest Law into Operation, Rules for compensating Damage of Protection Forests, Rules for managing Protection Forests, Rules relating to the Protection Forest Register, etc. The Register in question is of two kinds, one relating to privately owned forests and to be kept at the respective local offices, and the other relating to State forests and to be kept at the Major Forest Office concerned.

The control of State forests and plains is regulated by the Law relating to State Forests and Plains promulgated in March 1899 and it has attached to it a number of Rules and Regulations for putting it in execution.

The Law relating to the Restoration of State Forests and Plains to Original Owners was issued in April 1899, and by issuing at the same time several rules appertaining thereof measures were devined for returning to original owners State forests and plains incorporated into State property, provided the alleged owner's claim is judged to rest on valid ground. This special arrangement has been arcopted in view of the fact that not a few cases of incoporation hastiIy made soon after the Restoration have subsequently been discovered to have been not quite justifiable.

The: existence of the Forestry Fund as an acemut independent of ecucral account is a special feature in regard to the finance of forcts and plains belonging to the State, the fund in question being enployer for the special exploitation of forests, such as the survey- 


\section{$-65-$}

ing of State forests and plains, drawing up of their working plans, their planting, parchase of forests, etc.

The official organization of offices dealing with State forests and plains has been determined either in the shape of Imperial or Departmental Ordinances. 

$$
\text { . }
$$ 



\section{LIBRARY \\ FACULTY OF FORESTRY \\ UNIVERSITY OF TORONTO}

SD Japan. Nörinshō.

225 Sanrinkyoku

A5

1904

Forestry of Japan

Forestry

\section{PLEASE DO NOT REMOVE \\ CARDS OR SLIPS FROM THIS POCKET}

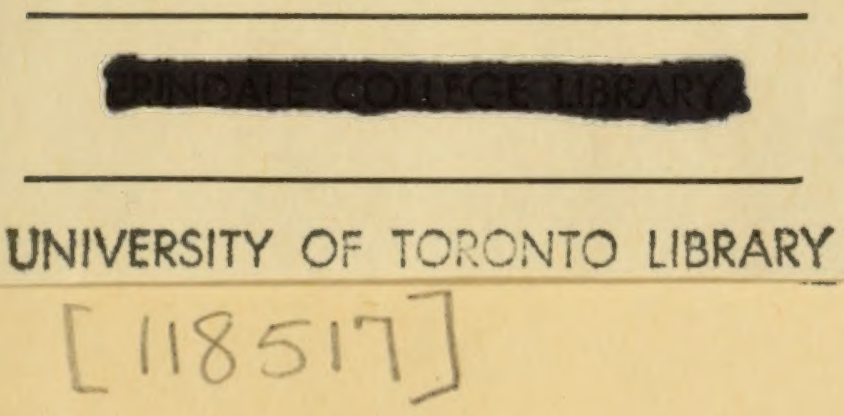




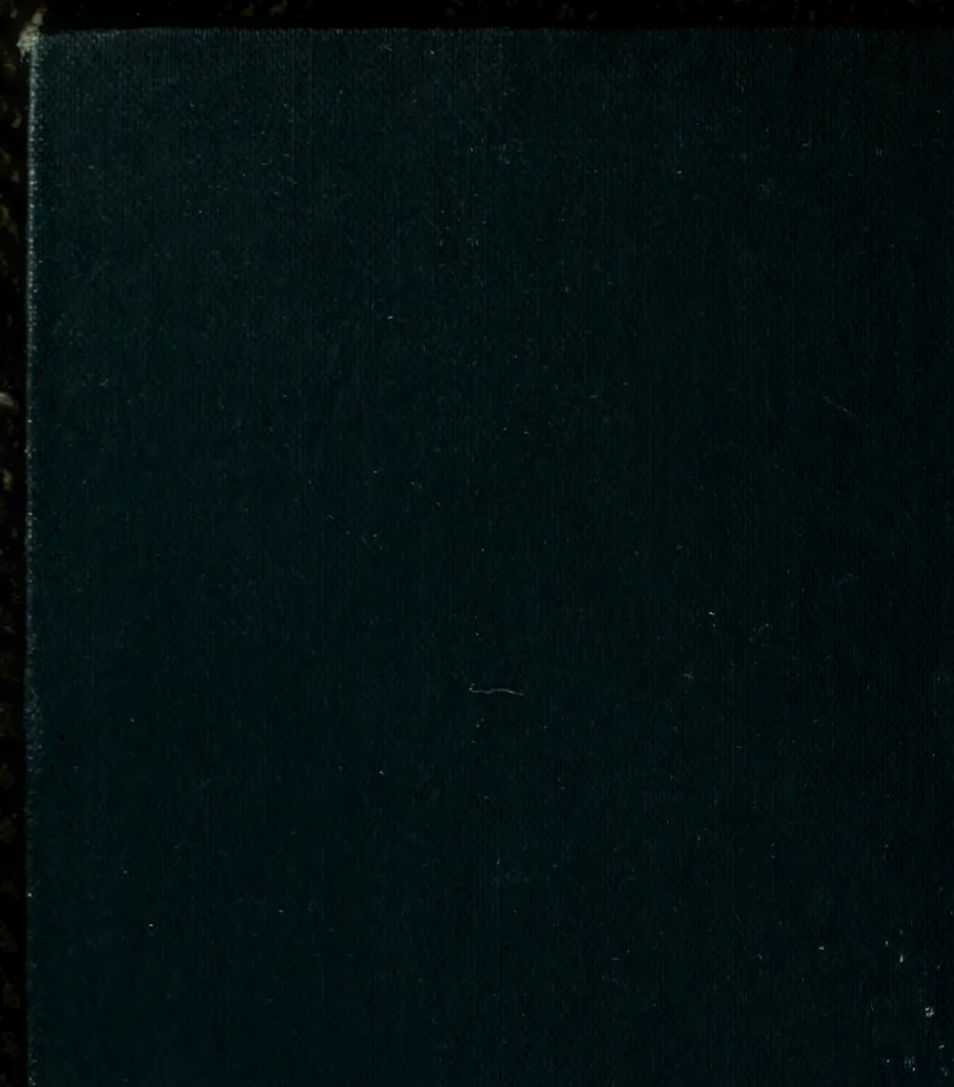

Kortentio

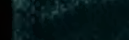

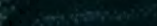

